\title{
Katastrofe i migracije: kritičko-hermeneutički pristup
}

DOI: $10.11567 /$ met.30.3.2

UDK: 502.58:314.7]:165.24

314.7:502.58]:165.24

Izvorni znanstveni rad

Primljeno: 10.9.2014.

Prihvaćeno: 23.10.2014.

\section{Vjeran Katunarić}

Odjel za sociologiju Sveučilišta u Zadru, Zadar

vjeran.katunaric@zg.t-com.hr

\section{SAŽETAK}

Polazeći od Sorokinova dualističkog (»unutrašnjeg« i »vanjskog«) objašnjenja kretanja te od proširenoga kritičko-hermeneutičkog poimanja svijeta života, u radu se najprije analiziraju neki primjeri mitologema/ideologema o migracijama. Nadalje se razmatraju povezanosti između katastrofa i migracija u životinjskom i ljudskom svijetu te kretanja stvari i ideja, posebno mita o »seobi duša«. Glavna (hipo)teza odnosi se na suvremeno zaustavljanje masovnih migracija ljudi s Juga na Sjever i uzima se kao posljedica propadanja ključnih projekata razvoja proizišlih iz ideologija liberalizma i socijalizma, pri čemu se, kao antimodernizacijski odgovor, u dijelu Juga reaktivira mitologem »seobe duša «. Katastrofe su, kao uzrok (masovnih) migracija, interpretirane kao fenomeni svijeta života na dva načina. Prvo, kao predmet vjerskih i znanstvenih svjetonazora koji postuliraju ništavilo ili nestanak (pojedinih) vrsta, kao preduvjet stvaranja (svijeta ili novih živih vrsta). Drugo, katastrofe su reinterpretirane s gledišta koncepta mnogostrukih univerzuma, koji je manjim dijelom analitički, a većim dijelom hermeneutički. U kozmologijama carstava prevladava ili idejni ili materijalni element monistički shvaćenog univerzuma. Uzdizanjem jednoga elementa na račun drugoga život se pojmovno cijepa na besmrtnu »migrantsku« dušu i propadajuće »starosjedilačko « tijelo (idealističko rješenje), odnosno gasi skupa s tijelom (materijalističko rješenje). Egzodus se kao motiv pojavljuje u gotovo svim kulturama skupa s mitom o »seobi duša «. Mit se danas reaktivira u područjima obuzetima militarističkom idejom »svetog rata«. U uništavajućem pohodu na svijet života ukrštaju se dva dugotrajna procesa koja potkopavaju (utopijsku) nadu u bolji život. Jedan se odnosi na širenje kapitalističke tržišne centrifuge, koja vodi siromašenju najvećeg dijela društava na Jugu. Drugi proces račva se u sekularnom smjeru (iseljavanje u sigurnije geografske prostore) $i$, jenjavanjem sekularnih migracija, sve više u iluzornome, apokaliptičkom smjeru. Jedini preostali mogući odgovor na tu rušilačku prijetnju golemih razmjera jest prevođenje ideje o mnogostrukom univerzumu u nova svjetska ulaganja, u (alternativni, pluralni) razvoj Juga (i Sjevera). Na taj način potencijalni iseljenik sudjeluje u izgradnji svoje zavičajne sredine, što iseljavanje $\mathrm{u}$ udaljene prostore čini nepotrebnim ili predmetom slobodnog izbora.

KLJUČNE RIJEČI: katastrofe, evolucija, razvoj, migracije, mitologemi, »seoba duša«, kritičko-hermeneutički pristup 
»Katastrofa je (...) uvijek bila dio procesa preispitivanja prošlosti« (Roskies, 1999: 310).

»Život je na neki način neprekidni proces, proces narastanja, mijenjanja i neprestanog nastajanja« (Jayaram, Transmigration Of Souls - A Buddhist Perspective).

»Na obalama rijeke Susquehannah [na kojoj je danas nuklearna elektrana »Otok tri milje«, poznata po svojoj havariji - V. K.] podići ćemo svoje šatore. Onamo će nas (...) slijediti svi miroljubivi sljedbenici jednakosti i slobode« (Tennant, 1998: 82).

»Prvi i najopćenitiji tip migracija uključuje religiozne osobe koje se sele da bi našle neku vrstu duhovnog i ekonomskog ispunjenja. Hodočasnici - obično pojedinci ili obitelji - migriraju na vlastitu inicijativu zbog složenih, međusobno povezanih razloga. To znači da se religijski, društveni i ekonomski faktori isprepleću da proizvedu migracije vjerski motiviranih pojedinaca, obitelji ili pak kongregacija « (Rohrer, 2010: 9).

»Posve sam uvjeren da se zemaljski raj nalazi na mjestu koje sam opisao« (Kristofor Kolumbo, 18. listopada 1498., u pismu iz San Salvadora španjolskom kralju Ferdinandu).

»Izučavanje pokretljivosti treba rasvijetliti skrivena i vidljiva kretanja ljudi, predmeta, slika, tekstova i ideja« (Greenblatt, 2004: 2). »Izučavanje pokretljivosti (...) u biti upućuje na ono što su srednjovjekovni teolozi zvali contingentia, osjećaj da svijet koji poznajemo nije nužan: ne samo da će nestati nego i da je sve moglo biti drugačije« (Greenblatt i sur., 2010: 16).

»Nije teško uočiti da se predmeti, zbog svoje duge povezanosti s ljudskim projektima i kontekstima, rijetko pojavljuju u izolaciji. $U$ tom pogledu oni su kao riječi« (Appadurai, 2013: 259).

\section{IZVORI TEME I OSNOVNI PRISTUP}

Ideje za temu ovog rada potječu iz različitih izvora. Prvi je djelo Pitirima Sorokina Društvena i kulturna pokretliivost (Sorokin, 1959), nastalo na osnovi njegova višesveščanog djela Društvena i kulturna dinamika (Sorokin, 1957). Za razliku od klasika teorije evolucije Herberta Spencera i Charlesa Darwina Sorokin glavne evolucijske procese razmatra i s »vanjske«, objektivne, i »unutrašnje «, subjektivne, strane. ${ }^{1} \mathrm{U}$ tom smislu opisuje i društvenu i pro-

Prema Sorokinu, promjene u sociokulturnoj, organskoj i anorganskoj stvarnosti podjednako podliježu »načelu imanentnosti«, što znači da se procesi u nekoj mjeri odvijaju prema pravilnostima svojstvenima svakom obliku stvarnosti, a u nekoj i pod vanjskim utjecajima drugih oblika stvarnosti (Sorokin, 1957: 630-638). S obzirom na ontologijski pluralizam Sorokin podsjeća na Nicolaija Hartmanna, jednog od posljednjih velikih metafizičara 20. 
stornu pokretljivost kao objektivni proces jer se odvija unutar $\mathrm{u}$ biti trajnog sustava društvene nejednakosti i pod utjecajem ekološke sredine. Pokretljivost kao subjektivni proces sastoji se od kretanja ideja, koje se nakon nekog razdoblja, prije svega u zapadnoj kulturi, bitno mijenjaju. Njihov utjecaj na prirodna kretanja osobito se povećava u modernoj epohi zbog primjene znanstvenih ideja u industriji, a utjecaj ideja na oblike političke vlasti velik je i u predmodernim epohama i u modernoj epohi.

Takvo višestruko poimanje kretanja, odnosno migracija, ipak nije imalo većeg utjecaja u društvenim znanostima. Tek odnedavno, zbog porasta interesa za različite procese globalizacije, koji se na mnogo načina međusobno ukrštaju, izučavanje migracija ljudi dovodi se u vezu s kretanjem ideja i stvari. Zagovornici višeslojnog pristupa fenomenu kretanja autori su postmodernističke provenijencije. Njima je i u ovom slučaju svojstveno da umjesto povezujućih teorijskih ideja o paralelnim ili ukrštajućim globalnim kretanjima nude složene opise stalnosti i promjenjivosti ili protočnosti elemenata kulture (Greenblatt, 2004; Greenblatt i sur., 2010; Appadurai, 2013).

Cilj je ovog rada ustanoviti moguću povezanost između različitih vrsta katastrofa i masovnih kretanja, odnosno migracija, u raznim oblicima svijeta života. Primjenom kritičko-hermeneutičkog pristupa ${ }^{2}$ pokušat će se upozoriti na povezanost između suvremene krize modernog razvoja, zaustavljanja migracija s Juga na Sjever i povratka apokaliptičkih sadržaja u središte društvene svijesti, sažetih u mitologemu »seoba duša«. Smisao objašnjenja sa stajališta kritičke hermeneutike srodan je dvostrukoj hermeneutici. ${ }^{3}$ Dvostruka hermeneutika polazi od činjenice da je svijet unaprijed interpretiran značenjima te ih kritički reinterpretira tako što $\mathrm{u}$ zatečenim značenjima razotkriva utjecaj vladajućih ideologija ili mitologija. ${ }^{4}$ Kritičkohermeneutičko razumijevanje ovdje je prošireno na simboličku povezanost različitih kategorija kretanja u kontekstu katastrofalnih situacija. Katastrofe

stoljeća i preteču kritičkog realizma u suvremenoj filozofiji i sociologiji (vidjeti fusnotu 6).

2 »Kritička hermeneutika ništa ne uzima zdravo za gotovo« (Radford, 1991: 25). Daljnja analiza najviše će biti posvećena subjektivnim značenjima katastrofe kao pokretača masovnih migracija ljudi i životinja, ali i određenih ideja, u prvom redu ideji o »seobi duša «. Zbog neurofizioloških stresova izazvanih većim poremećajima u okolini, životinje vjerojatno pate slično kao ljudi. O životinjama kao »semiotičkim bićima u u okviru stare hermeneutičke ideje o »knjizi prirode« vidjeti: Scheers, 2001.

3 Termin je uveo Anthony Giddens (1984: xxxii-xxxiii), a Habermas je usporedo razradio »dvostruku interpretaciju« kao način analize jezičnog sporazumijevanja ne samo u znanosti nego i društvenom svijetu života (Habermas, 1981).

4 Pojmove mitologija i ideologija autor ovog rada izjednačuje s obzirom na njihovu legitimacijsku funkciju koja se ogleda u prerušavanju središta vlasti u društvu u instanciju kozmičkih ili društvenopovijesnih zakona. 
su posljedica nemogućnosti rješavanja nagomilanih proturječnosti u postojećim okvirima. U prirodi propast jednih populacija ili vrsta često otvara put nastanku drugih. Donekle je slično s ekonomskim propadanjem, uz napomenu da se u modernoj epohi uspostavljaju etički i pravni korektivi (ljudska, posebno radnička prava, koja ne bi smjela biti narušena ekonomskom krizom ili katastrofom), dok u starijim epohama tome služi poglavlje $\mathrm{u}$ religijama koje se odnosi na smrt i seobu duša (u bolji svijet). Danas se zbog ulaska najvećeg broja zemalja Juga u slijepu ulicu razvoja, na što upućuje širenje međunarodnih i građanskih ratova u područjima Afrike, Srednjeg istoka i europskog Istoka, najstariji migracijski mitologem ponovo smješta u središnji okvir kolektivne svijesti.

Drugi izvor za ovu temu odnosi se na spomenuti paradoks kapitalističke globalizacije, koji je autor ovog rada prvi put jasnije uočio pišući knjigu o nacionalizmu i zaključio da nacija do daljnjega ostaje sudbinska nadlokalna zajednica, a u islamskom svijetu još i vjerska zajednica - na Jugu zbog nepokretnosti većine stanovništva, a na Sjeveru zbog toga što nadnacionalni savezi (uključujući Europsku uniju) pogoduju interesima nacionalnih gospodarskih elita, ali do »prve okuke«, tj. veće ekonomske krize, čime se političke kontraelite koriste za pokretanje popularnog nacionalizma, sve više u sprezi s retorikom (neo)rasizma usmjerenom protiv imigranata s Juga (Katunarić, 2003).

Što se tiče objašnjenja uzroka velikog nerazmjera između protokâ stvari i ljudi, postojeća literatura ponajprije upućuje na prirodu kapitalizma kao sustava koji fetišizira zaradu i obezvređuje radnike, kao i sve veći dio ljudi u najamnom odnosu (usp. Castles, 2004; Harding, 2012). Pa ipak, sklonosti suvremene vladajuće klase - blagonaklonost prema (trgovini) stvarima i zazor spram ljudi - mnogo su starije od kapitalizma. One vuku porijeklo iz robovlasničkih carstava. Starorimski robovi na primjer bili su tretirani kao "govoreće stvari« (res loquens). I njih se, kao radnike danas, odbacivalo kada bi ostarjeli ili oboljeli. Da su i na simboličkoj razini većini ljudi namijenjeni ponižavajući uvjeti života, razabire se u sve tri religije Knjige. Prema tim izvorima, ljudi su sapeti višim silama koje predstavlja svjetovna vlast. Takva legitimnost vlasti podjednako se utvrđuje idejno u sprezi s klerikalnim vjerskim svjetonazorom i materijalno, osiguravanjem trajnog poretka društvene nejednakosti i unutrašnjom opresijom i osvajanjem novih geografskih prostora. Zbog nepodnošljive težine takva poretka donji društveni slojevi najviše teže migracijama u sigurnije udaljene prostore. Ta se težnja najviše ostvaruje u modernoj epohi, ali na paradoksalan i nepouzdan način. Slo- 
bodno kretanje $\mathrm{i}$ »slobodni rad « ciničan je sinonim za najamni rad u teškim uvjetima.

Suvremeni kapitalizam, kao nova vrsta imperija, čini korak dalje u dvostrukome, vjerskom i svjetovnom, legitimiranju izvora društvenog poretka. Iako ne odbacuje religijski svjetonazor, nego ga tolerira iz zakonskih (nediskriminacija) i ideologijskih razloga (antikomunizam većine religija), više ga ne smatra dovoljno pouzdanim partnerom u poslu. Stoga izdašno podupire znanstveni svjetonazor, odnosno njegovu glavnu, pozitivističku struju. Iako religijski svjetonazor ima najduže iskustvo u odvraćanju od motiva pobune protiv vlasti, razvitkom modernijih oblika religijskih naučavanja, kao što je kršćanska teologija oslobođenja, i religija prestaje biti pouzdana saveznica vlasti.

Dotle matični tok znanstvenih istraživanja nagomilava empirijske dokaze i protiv religijske i utopijske nade. Prirodoznanstveni dokazi demonstriraju nepotrebnost Boga u stvaranju svijeta i evolucijskih linkova ka homo sapiensu. Ipak, najvažniji dokazi dolaze iz eksperimentalne fizike elementarnih čestica, u čijoj pozadini titra posebna vrsta ništavila. Stvaranje svemira, prema jednomu novijem objašnjenju, pokrenula je »kvantna fluktuacija« $\mathrm{u}$ »metastabilnoj lažnoj praznini« (He, Gao i Cai, 2014), dakle energija dovoljna da Pramjehur eksplodira i proizvode svoju suprotnost: svemir krcat galaksijama u čijim, relativno malobrojnim, kucima niče život.

Najobilniji dokazi koji upućuju na neostvarivost utopijskih težnji dolaze pak iz pozitivističkih dijelova povijesnih i društvenih znanosti, prema kojima budućnost, poput embrija, rekapitulira prošlost ponavljajući usud zbog kojeg se na Moć ne može upravljati odozdo, demokratski, i koja se, uzurpirana i u modernoj epohi, vraća na carsko prijestolje. Brojna istraživanja govore o neuspjesima donje klase u pokušaju poboljšanja položaja u društvu (usp. Foran, 1997). Rijetki uspjesi odnose se na društvenu pokretljivost koja rezultira napuštanjem niskoga društvenog položaja, poput preobražaja siromašnih imigranata $\mathrm{u}$ američke farmere $\mathrm{i}$ zapadnoeuropskih $\mathrm{u}$ »imućne radnike« države blagostanja. Ti su slučajevi iznimka, a općenito su tendencije egalitarizma podržane od liberalnih država na Zapadu i socijalističkih na Istoku trajale svega nekoliko desetljeća.

Zbog toga što, ničeovski rečeno, znanost »muški« odbija pružiti nadomjestak za religiju ili utopiju, njen je svjetonazor najsrodniji tragičnome: slavni umiru u svojoj veličini i idući ih naraštaji dugo pamte, dok se ostalima ubrzo gubi trag, najprije u pamćenju šire zajednice, a onda i među 
potomcima. ${ }^{5}$ Argumenti znanosti akumuliraju se u jedinstvenoj monističkoj, materijalističkoj perspektivi. U toj perspektivi stvari se, od jednostavnih čestica (zvjezdane prašine) do složenijih bića i (na kraju?) čovjeka, razvijaju sua sponte, bez vanjskog utjecaja. Analogno tome, idealistička perspektiva razvitak stvari poistovjećuje s razvitkom ideje kao nezavisne sile kojoj je materijalna strana instrument u izvedbi, koja baš ne ispadne uvijek dobro, pa je u biti sporedna, prividna i nestajuća. Nasuprot tome, dualistička perspektiva kombinira argumente materijalizma i idealizma: stvari se razvijaju ukrštanjem unutrašnjih i vanjskih utjecaja, pa su materija i duh međusobno prožeti i nerazdvojni. ${ }^{6}$ To je, valja pretpostaviti, ontološko polazište fizičara i nuklearnih inženjera koji upućuju na mogućnost postojanja mnogostrukih svemira. ${ }^{7}$ Premda se kao i istraživači iz monističke perspektive služe matematičkim jednadžbama i koriste rezultatima nekih eksperimenata, njihovi se argumenti (još uvijek) nalaze u području hermeneutike. Takvu razumijevanju više ususret ide umjetnost, ili barem njezin dio, nego analitička znanost: na primjer Monetove slike jedne te iste (?) katedrale u različita doba dana ili Cezanneove brojne, ali nikad identične, slike brda Saint Victoire. Pa ipak, (hipo)teza o različitim svjetovima koji su nekako međusobno spojeni ili umreženi može se - sve dok se u eksperimentalnoj fizici mikročestica eventualno ne pronađu njihova dodirna mjesta - (p)održavati intuitivno ili pak deduktivno pod aksiomatskom pretpostavkom o neuništivosti Života. Iz toga proizlaze (teorijske) pretpostavke o neograničenim mogućnostima seobe životvornih, idejno-materijalnih entiteta u pogodn(ij)a područja

U tome je slaba strana antireligijskih argumenata znanosti. Pokušaji uglednih znanstvenika, poput evolucijskog biologa Dawkinsa, da rastjeraju vjersku maglu argumentima (Darwinove) teorije evolucije čine se uzaludnima. Osim toga klasična modernizacijska pretpostavka o učincima sekularizacije, po kojoj viši stupanj razvitka gospodarstva i demokracije, odnosno obrazovanja, nužno dovodi do opadanja religioznosti, pokazala se pogrešnom (usp. Casanova, 2008). U svakom slučaju, isključivo znanstveni dokazi o nepostojanju sveopće inteligencije koja upravlja svijetom nisu ni izdaleka dovoljni da bi se većina ljudi pomirila s apsurdnošću individualnog života i njegovim nestankom u mraku ništavila.

6 Ontološki dualizam, inače jedan od izvora kritičkog realizma u suvremenoj filozofiji i sociologiji, najpotpunije je razrađen u djelu Nicolaija Hartmanna. On idealno i realno prikazuje aristotelovski, kao nerazdvojne elemente zbilje. Jednom ili drugom elementu može se pripisati viši ili niži rang, ali svejedno se ni tada ne mogu smatrati zasebnim oblicima zbilje (Hartmann, 1976). No ni dualistička perspektiva - u ovom slučaju predstavljena konceptom mnogostrukih svemira - nužno ne podrazumijeva ulogu Boga, polazeći od pretpostavke (između ostaloga u skladu sa starogrčkom mitologijom i dijelom filozofije /npr. Heraklitove/) da svijet nije nikada stvoren, već postoji oduvijek.

7 Vidjeti populariziranu i raznim religijama prilagođenu verziju na web-stranici: http:// www.learning-mind.com/quantum-theory-proves-that-consciousness-moves-to-anotheruniverse-after-death/ (23. 06. 2014.). 
ili svjetove. Štoviše, upravo migracije, sa stajališta motiva koji tjeraju ljude od situacije katastrofe, iziskuju trajno postojanje različitih svjetova života. ${ }^{8}$ Iako još duboko različita, poimanja pluralističkog i monističkog univerzuma imaju barem jedno zajedničko polazište, a to su situacije katastrofa kao jedni od najznačajnijih događaja u evoluciji. Zaključci koji iz toga slijede različiti su. U monističkoj interpretaciji katastrofe otvaraju mogućnost nastanka novih vrsta, dok u pluralističkoj nepovratnoga gubitka života ne mora biti jer bića mogu, skoro neokrznuta katastrofom, prelaziti iz svijeta pogođenoga katastrofom u drugi svijet. Utoliko je, naravno, zadaća teorije pluralističkog univerzuma mnogo teža od teorije jednoga jedinoga univerzuma jer pokušava pružiti smisleni odgovor na prokletstvo besmislenosti opstanka u monističkom univerzumu, svijetu u kojem jedna katastrofa smjenjuje drugu sve do utrnuća univerzuma. ${ }^{9}$

Treći izvor za ovaj rad tiče se ideologijskog obilježavanja vanjskih migracija u bivšoj Jugoslaviji. ${ }^{10}$ Odmah po otvaranju državnih granica za odlazak

8 Što se tiče najtežih katastrofa, kao što su kataklizmički potresi koji su gutali čitave gradove i civilizacije ili nacistički genocid nad Židovima (zločin kojem se, za razliku od prirodnih razaranja, moglo suditi), razmatranja načina »bijega« ljudi zatečenih katastrofama, što uključuje kontroverznu mogućnost bijega u paralelne svjetove (o tome u kontekstu popularne fizike vidjeti: Greene, 2011), nešto je o čemu nerado govore, ali ipak napominju da predmnijevaju o čemu se radi, najozbiljniji autori kao što je Hannah Arendt u svojoj knjizi u kojoj govori, između ostaloga, i o svojim razgovorima s preživjelima u Holokaustu (Arendt, 1996).

9 Normativno razumijevanje svijeta $\mathrm{u}$ ovom radu, kao neograničenoga migracijskog prostora, nije upereno protiv sadržaja naučavanja moderne znanosti ili monoteističkih religija, već protiv njihove instrumentalizacije u službi vladajućih ideologija. Kao prvo, pobijanje mogućnosti postojanja Boga ili mogućnosti seobe duša nemoguća je misija ako ni zbog čega drugog, a ono zbog poštovanja slobode izražavanja na načelima suprotnima znanstvenom empirizmu ili dijelovima analitičke filozofije. Drugo, svaka argumentacija nastavlja se na prethodnu. Ali prethodni argument ne može se poništiti, nego samo dokinuti, uključiti, u najmanju ruku kao premisu, u novi argument, odnosno zaključak. Naposljetku, i vjerska i znanstvena naučavanja nastaju reinterpretacijom nalik na dvostruku hermeneutiku: preinačivanjem značenja zatečenih uvjerenja. Takav je primjer budističko-lamaistička preinaka hinduističkog nauka o karmi i karmičkim iluzijama (o krajoliku posmrtnoga kretanja pokojnikove duše) (usp. Evans-Wentz, 1998).

10 Autor ovog rada započeo je 1973. svoj znanstvenoistraživački rad na području vanjskih migracija u Centru za istraživanje migracija (u sklopu Instituta za geografiju Prirodoslovnomatematičkog fakulteta u Zagrebu). Centar je bio jedna od dviju jezgara iz kojih je nastao današnji Institut za migracije i narodnosti u Zagrebu. Na temelju analize rezultata jednoga anketnog istraživanja o školskoj djeci vanjskih migranata iz Hrvatske obranio je magistarski rad Nepokretne migracije (kao knjiga objavljen je pod naslovom Vanjske migracije i promjene u porodici /Katunarić, 1978/). Taj je (aristotelovski) izraz upotrijebio namjesto izraza berlinske istraživačice migracije Ayse Kudat bilocirana (termin iz parapsihologije i fizike elementarnih čestica!) obitelj (obitelj u kojoj je jedan roditelj /najčešće otac-muž/ ili su oba na radu u inozemstvu, a djeca su /bila/ ostala u domovini na skrb rodbini). Dakle $\mathrm{i}$ istraživačka terminologija, barem u to vrijeme, koristila se metaforama koje su služile ili još uvijek služe kao mitologemi. 
na rad u zapadnoeuropske zemlje u drugoj polovini šezdesetih godina 20 . stoljeća, u politici vanjskih migracija pojavio se službeni naziv »radnici na privremenom radu $u$ inozemstvu«. Njime se očigledno sugeriralo da će se radnici još u svojoj radno aktivnoj dobi vratiti u domovinu i nastaviti raditi. U najvećem broju slučajeva to se nije dogodilo, pa se "privremena« odsutnost pretvorila u trajnu. Time se urušio jedan od stupova vladajuće ideologije, premda Partija nikada nije priznala svoj poraz u očima radnika koji su iz zemlje samoupravnog socijalizma pohrlili u kapitalizam. ${ }^{11} \mathrm{~S}$ druge strane, kooptacijom termina »tržišna ekonomija«, kao sastavnog dijela socijalizma (usp. Korošić, 1988), odlazak radnika smatran je normalnim u sklopu (univerzalnoga) tržišnog zakona ponude i potražnje. ${ }^{12}$

Nove fraze ipak nisu pomogle da se uravnoteži ekonomski razvoj zemlje. U osamdesetima Partija je lansirala još jedan ideologem srodan »privremenosti«: »krizu«, razdoblje teškoća nakon kojih je trebao nastupiti oporavak. Iako se ni to nije dogodilo, nego ratna katastrofa, »krizološki« diskurs preuzele su nove države na tlu bivše Jugoslavije. »Krizom« se označuje dugotrajnija situacija u kojoj nepovratno propadaju poduzeća i radna mjesta, rasprodaju se javna dobra te rastu dugovi i siromaštvo. Ta preobrazba sve više podsjeća na »izvanredno stanje«, kojim Giorgio Agamben označuje modus operandi suvremenoga kapitalizma i uspostavu nove policijske države (Agamben, 2008).

Kao ni bivši socijalizam, liberalni kapitalizam ne može ispuniti želje većine ljudi za trajnim poslom i sigurnošću, osobito ne ljudima na periferiji. Političke stranke samo demagoški nadražuju te želje u predizborno vrijeme, ali ubrzo nastavljaju s programima koji potkopavaju životne izglede većine. Budući da je riječ o nemaloj promjeni, povijesnom koraku unazad prema restauraciji staleškog društva, ${ }^{13}$ a imajući na umu da su pokušaji većih migracija s Juga na Sjever praktično onemogućeni, nameće se zaključak da iza masovnog razočaranja učincima liberalizma i socijalizma slijedi novo masovno utjecanje religijama (onostranosti). ${ }^{14}$ Stoga su se i "privremene«

11 Pritom je krivnju za neuspjeh projekta radničkog samoupravljanja Partija nastojala prebaciti na nacionalizam kao petokolonašku ideologiju uvezenu sa Zapada. O presudnom udjelu vanjskih migracija u okretanju leđa nezadovoljnih radnika Partiji vidjeti: Katunarić, 2013.

12 Poraz jugoslavenskoga socijalističkog samoupravljanja bio je i veliki udarac za razvojne nade mnogih zemalja Juga, učlanjenih u Pokret nesvrstanih, jer je posrijedi bio projekt samostalnog razvoja utemeljenog na domaćim znanjima i industrijama.

13 »Mi se krećemo unatrag! Ne idemo samo prema 1917., nego idemo unatrag prema feudalizmu«, glasi izjava jednoga ruskog seljaka prenesena u: Verdery, 1996: 204.

14 Da takvi simptomi uzimaju maha, pokazuju učestali teroristički činovi s bombašima samoubojicama, čiji ih organizatori uz pomoć vjerskih »ispiratelja mozga« pripremaju na 
razvojne teškoće $u$ bivšem socijalizmu prometnule $u$ trajne. To je zlo međutim nastalo mnogo ranije, ${ }^{15}$ prije i nego što su Marx i Engels 1848. u Кomunističkome manifestu oslikali kapitalizam kao sustav u kojem »sve što je (...) čvrsto i postojano pretvara [se] u dim, [i] sve što je sveto biva oskrnavljeno « (Marx i Engels, 2008: 569). Ta slika jednako tako nalikuje na biblijsku apokaliptičku viziju nemani koja spaljuje sve pred sobom, kao i na nacističke spalionice za Židove i druge »niže rase «. ${ }^{16} \mathrm{U}$ isti niz prizora uklapaju se bezobzirna masovna otpuštanja s posla ljudi koji više ne mogu naći posao i čije šanse dužeg preživljavanja zbog toga opadaju. ${ }^{17}$

Zbog sve učestalijih društveno-ekonomskih katastrofa i tendencija militarizaciji svijeta (rast industrijskog sektora u najrazvijenijim zemljama dobrim dijelom otpada na povećanu proizvodnju oružja) te zbog nizanja zasad još lokalnih ratova (usp. The End of the Development-Security Nexus?, 2012) sve većem broju ljudi eventualne migracije prema sigurnijim područjima na Sjeveru predstavljaju posljednju solidnu životnu šansu. No Sjever je blokirao taj protok ljudi, čime se cjelokupni razvoj našao u slijepoj ulici. To je prilično česta pojava u evoluciji prirode i nerijetka u povijesti razvoja civilizacija (usp. Runciman, 1989). Primjeri su nestanci mnogih vrsta životinja, neandertalca, pojedinih kultura i civilizacija (harpanske, Maja...) te brojnih jezika manjih naroda. Ali i protagonisti kolonizacije novih prostora još od Kolumba dolaze iz područja pogođenih katastrofom, ako ne ekonomskom, onda kulturnom. Kolumbo, kraljevski opunomoćenik, stigao je na Karipsko otočje iz Španjolske u doba rekonkviste, masovnog istjerivanja Arapa s Iber-

trenutačni »ulazak u raj« po izvršenom zadatku.

15 »Đavo je star« i »dijabolična sila« - tim demonizirajućim konotacijama Max Weber obilježava preddemokratsku političku vladavinu (Weber, 1999), svakako mnogo stariju od kapitalizma u pokušaju uspostave trajnog nadzora i nasilja nad ljudima.

16 Uspoređujući obilježja (suvremene) korporacijske prakse i organizacijske prakse nacističkoga Holokausta, Stephen Halebsky ističe da je namjera nacista da Židove iskoriste kao radnike i onda ih spale bila utoliko »iracionalna (...) jer im je bila nasušno potrebna radna snaga za održavanje proizvodnje. Ono što valja istaknuti [međutim] (...) jest u kojoj su se mjeri korporacijski zaposlenici prilagodili tom užasnom programu (...) Dok bi bilo naizgled nekorektno tvrditi da tipična korporacija svoje radnike tretira jednako loše kao IG Farben, uočljiva je tendencija velikog biznisa da zaposlene tretira nehumano, posebno nekvalificirane i nisko kvalificirane radnike. Ta je tendencija očigledna uzme li se u obzir način na koji je veliki biznis tretirao radnike prije nego što su doneseni zakoni o zaštiti na radu i kako su radnici danas tretirani kada je takvo zakonodavstvo slabo ili nepostojeće« (Halebsky, 2014: 248).

17 Istraživanja nepobitno dokazuju povezanost društvenog položaja i životnih izgleda ljudi: »Zdravlje slijedi društvenu ljestvicu: što je viši položaj u društvenoj hijerarhiji, manji je rizik od lošeg zdravlja i prerane smrti« (Uzzoli, 2011: 8). Nije teško zamisliti stanje u nekom zdravstveno-ekonomskom feudalizmu, uz daljnji brzi napredak medicine, gdje bi ljudi bez novca i javnozdravstvene skrbi umirali kao muhe. 
skog poluotoka, tristotinjak godina nakon masovnog istjerivanja Židova. Te katastrofe kao da su najavile raspade multikulturnih sredina, od Njemačke tridesetih godina 20. stoljeća do Bosne i Hercegovine ili Ukrajine danas. Sve su one proistekle iz istoga pogrešnog uvjerenja da zajednički život različitih ljudi nije moguć. Elementarna je istina međutim posve drugačija, a dokaz su gotovo neprekidne migracije. Afrika je pradomovina svim ljudskim skupinama, a domovine su postaje na dugom putu koji još traje.

\section{POLAZIŠTA I ODREDIŠTA MIGRACIJSKIH KRETANJA U RAZLIČITIM SVJETOVIMA ŽIVOTA}

Povezivanje ${ }^{18}$ migracijskih kretanja $\mathrm{u}$ raznorodnim oblicima zahtijeva proširenje značenja svijeta života ${ }^{19}$ na kretanja ideja i proizvedenih predmeta, dakle artefakte novog sloja kulture, ljudske, u odnosu na slojeve kultura drugih vrsta. ${ }^{20}$ Ljudske sposobnosti stvaranja artefakata, zamišljanja i planiranja situacija, diferenciranoga jezičnog, likovnog i glazbenog izražavanja te seoba na veće udaljenosti izgradnjom infrastrukture za stanovanje i stvaranjem novih ideja vodilja, omogućuju udobnije uvjete opstanka. No i tu postoje ograničenja. $U$ odredišnim sredinama ne mijenjaju se svi uvjeti u odnosu na polazišne. Sorokin je ustvrdio da je društvena stratifikacija okvir u kojem se odvija kretanje ljudi i njihovih ideja. Isto vrijedi, kao što ćemo vidjeti, i za migracije životinja. Kretanja različitih skupina organizama, predmeta i ideja usmjerena su prema nekom subjektivnom cilju, ali je domet ograničen objektivnim uvjetima, ponajprije društvenom hijerarhijom. Nehijerarhizirane vrste pak, bilo da je riječ o najranijim (egalitarnim) ljudskim zajednicama ili životinjskim skupinama koje se kreću u rojevima, u

18 Autor ovog rada u dostupnoj literaturi nije naišao na ovdje iznesenu kategorizaciju migracija, nego samo opise pojedinih kategorija pod tim ili srodnim nazivima. Ni za predložena objašnjenja koja povezuju raznorodne kategorije kretanja, tj. migracija i »migracija«, nema predloška u dostupnoj literaturi. To je dobro što se tiče originalnosti pristupa, a loše što se tiče nedostatka odgovarajućih teorijskih uporišta u literaturi i autor je svjestan znanstvenog rizika koje sobom nosi, podjednako kao i »otkrivanja tople vode«, interpretacije koja podsjeća na Kolumbovo miješanje biblijske fikcije raja s ljepotom novootkrivenoga kontinenta.

19 Termin svijet života upotrebljava se (kod Husserla, Schütza i Habermasa) za predznanstvene opise (samo)razumijevanja ljudskih sredina. Ovdje se termin upotrebljava u značenju ukupnosti različitih simbolički umreženih životnih zajednica, iz čega se mogu raspoznati i elementi ljudskog svijeta; vidjeti fusnotu 2.

20 Izučavanje životinjskih kultura u velikom je zamahu, premda je pojam kulture u odnosu na ljudsku kulturu samo analogan i najčešće poistovjećen s tradicijom i društvenim učenjem. Ipak, neke crte ponašanja ljudi i životinje dijele (Ramsey, 2013), uključujući tipove migracija (vidi dalje u radu). 
gotovo istome međusobnom odnosu (jednakih jedinki) smještaju se u novi prostor. Jedinke hijerarhiziranih vrsta, što pokazuje i najraniji hinduistički nauk o reinkarnaciji, ne mijenjaju mjesto u hijerarhiji čak ni u zamišljenim zagrobnim svjetovima. Općenito, različite kategorije migracija predstavljaju različite oblike svrhovitoga kretanja - kod životinja nagonski uvjetovanoga, a kod ljudi pretežno svjesno i najčešće povezano zajedničkim mitom o obećanoj zemlji (usp. Smith, 1986).

Također, činjenica da su različiti svjetovi međuzavisni ne znači da su i međusobno usklađeni. Jedan od glavnih uzroka leži u katastrofama kojima je svijet života isprekidan u prirodnoj evoluciji i ljudskoj povijesti. Potonje su osobito učestale u najmlađoj, modernoj epohi, ${ }^{21}$ na čijem je pročelju, paradoksalno, uklesana (Kantova) ideja o vječnome miru i razumijevanju među ljudima i narodima. Jedan od uzroka te diskrepancije leži u činjenici što se u otporu izgradnji modernog društva udružuju snage starijih hijerarhijskih društava, što rezultira čestim reakcionarnim protuudarima i restauracijama.

Prije potanjeg razmatranja povezanosti katastrofa i masovnih migracija valja imati na umu upozorenje jednog od vodećih istraživača u tom području Josepha Taintera da su prirodne katastrofe jednako važne za objašnjenje propasti pojedinih društava kao i ekonomske katastrofe. ${ }^{22}$ Tome valja pridodati i utjecaj idejnih katastrofa. ${ }^{23}$

Opisi raznih kategorija migracija koji slijede usredotočeni su na odnos katastrofa i pojedinih tipova migracija i, u skladu s tim, pokušaja odlaska na sigurnija udaljena mjesta.

${ }_{21}$ Na europskom kontinentu od 1492. do 1991. bilo je, prema izračunu Charlesa Tillyja, ukupno 707 godina »revolucionarnih situacija « (većih sukoba s upotrebom fizičkog nasilja) (Tilly, 1993: 243). Tome valja pridodati brojne valove seoba u prostore nezahvaćene sukobima.

22 »Nema jasne granice između teorija katastrofe i teorija iscrpljenja resursa, već samo suptilne razlike (...). Scenariji katastrofe su drevni. Platonova djela Kritija i Timej opisuju nestanak mitske Atlantide na sličan način. Biblijska poplava i srodne priče spadaju u istu temu« (Tainter, 2007: 96). Vidjeti slično objašnjenje društvenih katastrofa u: Runciman, 1989: 310 i d.

23 Ponajprije su ideje i politike nametnute bez razložnog pristanka većine ljudi i bez njihova otpora, dakle nedemokratski, izvori društvene katastrofe, iako se najčešće zbivaju uslijed obračuna među društvenim elitama, a ne između vladajućih i potlačenih klasa. Slično je s nerazmjernim trošenjem prirodnih resursa Zemlje od nekolicine industrijski najrazvijenijih zemalja obuzetih idejom neprekidnoga gospodarskog rasta. 


\section{Migracije životinja}

Najmanje jedan katastrofalni događaj u prirodi prije 66 milijuna godina, udar meteora (širokog četrnaest kilometara) u blizini Yucatana, ${ }^{24}$ uzrokovao je izumiranje dinosaura i masovne seobe ugroženih vrsta, ali i otvorio mogućnost za nastanak čovjeka (Benton, 2011; Posner, 2004).

Migracije su raširena pojava u životinjskom svijetu. No, kao ni ljudske, ni životinjske migracije ne mogu se objašnjavati mehanicistički, samo kao reakcija na poremećaje u prirodi (Bauer i Calssen, 2013; Hein, Hou i Gillooly, 2012; Hays i Scott, 2013). Tako postoje značajne varijacije među (pod) vrstama, pa i individualne razlike među članovima iste skupine s obzirom na migracijsku dilemu (Newton, 2012; Shaw i Levin, 2011; Li, Zhang i Yin, 2014). Individualne razlike imaju udjela i u tipu migracija koji je najrašireniji i kod ljudi, djelomičnim migracijama, koje nisu izazvane katastrofama, a obično migrira manji dio populacije. ${ }^{25}$

Uzrok jednom tipu migracija vezan je uz napuštanje izvornog staništa, $\mathrm{u}$ koje se životinje više ne vraćaju (removal migration). Do toga može doći zbog nedostatka hrane, neoprezne intervencije ljudi ili pak natjecanja s drugim životinjskim vrstama, što se može podvesti pod uvjete koji vode katastrofi. Slično je s potpunim migracijama, u kojima čitave vrste mijenjaju obitavalište, najčešće zbog iznimno niskih temperatura, s tim što se nakon hladne sezone znaju vraćati u prvotno obitavalište. Višegeneracijske migracije jedinstveni su fenomen. U njima se dio populacije rađa i reproducira, pripadnici starije generacije umiru, a selidbu nastavljaju mlađe generacije ili njihovi potomci. Ipak, u tom i drugim tipovima migracija u kojima su uvjeti preživljavanja teški najveći dio životinja preživljava seobe, što se objašnjava uspješnom evolucijskom prilagodbom na nepovoljne uvjete na putu do odredišta). ${ }^{26}$ Osim te sličnosti životinjske migracije dijele s ljudskima slične reakcije na ekološke promjene. Ekološki učinci današnjih klimatskih promjena (ne ulazeći u njihove uzroke) utječu na veličinu i vrijeme migriranja životinja. Zna-

24 Druge paleontološke teorije govore o kišama meteorita i brojnim vulkanskim erupcijama, http://news.nationalgeographic.com/news/2013/13/130212--chicxulub-asteroid-dinosaursvolcano-mass-extinction-environment-science (23. 05. 1914.). Ipak, ni one, kao ni teorija o učincima golemog asteroida, ne pobijaju ulogu slučajnosti ili nepredvidivih događaja u evoluciji. Otvoreno je pitanje jesu li (samo) ti slučajevi (bili) presudni za daljnje tokove evolucije.

25 http://www.buzzle.com/articles/types-of-migration-in-animals.html (23. 05. 2014.). U dostupnoj biologijskoj literaturi nema referenci o istraživanjima o specifičnom utjecaju (hijerarhijske /ili despotske - česti termin u zoologiji/ i egalitarne) društvene strukture životinjskih zajednica na migracije.

26 http://www.buzzle.com/articles/types-of-migration-in-animals.html (23. 05. 2014.). 
čajne su promjene nastupile na primjer kod anadromskih riba (koje žive $\mathrm{u}$ morima ili oceanima, a reproduciraju se u slatkim vodama). Porastom temperature i kišnih razdoblja, uslijed čega se povećava proizvodnja hranjivih tvari u jezerima, te ribe sve manje migriraju, što značajno smanjuje njihovu populaciju na Arktiku (usp. Finstad i Hein, 2012).

Iako ni izdaleka (još) nema uvjeta za nestanak većine životinjskih vrsta uslijed širenja suvremene ljudske civilizacije, valja se pitati bi li postojećim tempom i sve gorim ekološkim učincima gospodarskog rasta mogao biti doveden u pitanje i opstanak (većeg) dijela ljudske vrste. Iako danas na rubu gladi preživljava oko dvije milijarde ljudi (The State of Food Insecurity in the World 2010, 2010), koji žive u mnogo gorim uvjetima od milijuna kućnih ljubimaca u bogatim zemljama (uz napomenu da je psima i mačkama u gradovima siromašnih zemalja opstanak podjednako težak kao i ljudima) - te iako trenutačno nema trenda povećanja broja gladnih u svijetu - posvemašnja nezainteresiranost $\mathrm{u}$ razvijenim zemljama za opstanak velikih dijelova čovječanstva upućuje na mogućnost daljnjeg povećavanja siromaštva i gladi (usp. Dhaouadi, 2002).

\section{Migracije ljudi}

Zbog preopširnosti ove teme, jer su ljudske migracije ne samo posljedica prirodnih, na primjer klimatskih, promjena nego i velikog broja različitih povijesnih događaja, prikaz ove kategorije migracija bit će ograničen na suvremene međunarodne migracije. Kao i međunarodni trgovinski odnosi međunarodne migracije dobrim dijelom odražavaju postkolonijalne veze. Naime bivša kolonijalna carstva, od Britanije do Španjolske, radije prihvaćaju migrante iz svojih bivših kolonija nego iz drugih zemalja; također s bivšim kolonijama održavaju preferencijalne trgovinske veze (Davis i sur., 2013; Brysk, Parsons i Sandholz, 2002). To međutim ne znači da razvojna politika postaje humanija, da se britanski Commonwealth skrbi za siromašne dijelove Indije ili Francuska za sirotinju u Alžiru, Maliju i Čadu. U migracijama unutar bivših imperija i izvan njih ugrađeni su »filtri«. Na primjer migracije između Meksika i SAD-a i Turske i EU-a strogo su nadzirane s tendencijom njihova trajnog zaustavljanja. Doduše prisilne migracije, koje uključuju etničko čišćenje i ilegalne migracije, donekle narušavaju to pravilo, ali ga zato potvrđuju migracije-po-pozivu, odnosno migracije stručnjaka (brain drain, brain gain, intelektualne migracije). ${ }^{27} \mathrm{Na}$ taj način migracije prije

27 Taksonomi su preuzeti iz: Reisman, 2011. 
dopunjuju nego što dovode u pitanje poredak moći: »kretanja izvan, preko ili unutar ograničenih teritorija služe reprodukciji teritorija okruženoga granicom« (Steinberg, 2009: 457).

Suvremeni obrazac međunarodnih migracija proizlazi iz duge povijesti prisilnih, slobodnih i prijelaznih vrsta migracija. U većini slučajeva migracije radnika rezultat su ekonomskih prisila (»slobodnog rada«), a ne fizičkog nasilja. Slično su migracije u Europi u 16. i 17. stoljeću najviše proistekle iz vjerskih opredjeljenja (protestanata, katolika, Židova, muslimana...), a nakon 1950. bile su i rezultat političkog izbora među Nijemcima iz Istočne Europe (Lucassen, Lucassen i Manning, 2010: 3-38). U svakom slučaju, rastuća selektivnost međunarodnih migracija ide na štetu siromašnog stanovništva Juga, za razliku od razdoblja do šezdesetih godina 20. stoljeća. Doduše migracije same ne rješavaju problem siromaštva i prateće razvojne probleme - Jug se ipak ne može preseliti na Sjever.

Što se tiče političkog odgovora Sjevera na razvojni zastoj i »migracijski pritisak « Juga, na primjer u EU-u prevladava mišljenje, ali doista samo mišljenje, da bi od proširenja članstva EU-a bilo humanije i djelotvornije globalno koordinirati pomoć najugroženijim zemljama i u okviru toga preobraziti UN-ov projekt izgradnje mira (peace building) u projekt izgradnje ekonomije i društva, čime bi se uklanjali uzroci, a ne posljedice, migracije izbjeglica (Bade, 2003: 331-333). Iz toga se ne može zaključiti ništa drugo nego da je jedini djelotvoran odgovor na »migracijski pritisak « poznat već pedesetak godina pod nazivom države blagostanja. Ovog bi puta to morao biti regionalni projekt razvoja ekonomija, društava i političke demokracije u zemljama Juga (opširnije u: Czaika i de Haas, 2014; Hoerder, 1994). Dopunsku mogućnost pružaju »dolazni gradovi«, poput Los Angelesa, Nairobija, Shenzena i Rio de Janeira, koji bi u 21. stoljeću, zahvaljujući skoro neprestanome gospodarskom rastu, mogli prihvatiti relativno velik broj migranata iz siromašnog Juga (Saunders, 2011). No strah od novih valova izbjeglica uz tvrdoglavo ustrajavanje u doktrini slobodnog tržišta i privatizacije čine stav Zapada u cjelini licemjernim.

Postojeće stanje više od razvojnih pobuđuje neproduktivne, apokaliptičke vizije katastrofe. Dok je apokaliptička ideja zanosila puritanske useljenike u izgradnji Amerike kao instancije eklezijastičke povijesti (usp. Zakai, 2002), današnji apokaliptički žanr predstavlja represivnu desublimaciju. To se ponajprije odnosi na militarističku verziju džihada, trenutačno najokrutnije izvedenu širenjem takozvane Islamske države Iraka i Levanta. Ona otvoreno računa na veliku financijsku potporu naftonosnih šeikata, a još više na velike zalihe očaja i antizapadnjačkog resantimana na Jugu, iz čega 
bi se neprestano regrutirali novi samopožrtvovni borci za koje bojište predstavlja odašiljač duša muškaraca poginulih za pravednu stvar na drugi svijet u kojem ih očekuju razdragane ljepotice.

$* * *$

Katastrofe uzrokuju velike pomake i u drugim kategorijama kretanja - cirkulaciji proizvoda, koja je danas asimetrična i isprekidana zbog ekonomske katastrofe Juga, koja je pogodovala izvoznicima sa Sjevera, te $\mathrm{u}$ kretanju ideja, među kojima, zbog širenja vladajuće ekonomske doktrine i prakse "stvaralačkog razaranja « (taj Schumpeterov termin danas sve više sliči glavnome simboličkom pretku: masovnom umiranju uz utješni mitologem »seobe duša «), sve više propada utopijska nada kao uobičajeni pratilac modernih migracija.

\section{Kretanje roba}

Predmeti su se i prije ljudi kretali, bilo učincima prirodnih procesa (npr. erupcije vulkana), bilo kao posjed životinja koje ih ne obrađuju i ne prenose na veće udaljenosti (npr. ubiranje i raspodjela plodova kod majmuna ili zrnaca tvari kod mrava). Ni složeni proizvodi, poput robota, još se ne pokreću sami, bez dodira ljudske ruke. No tendencija potpuno programiranom kretanju predmeta bez sumnje se razvija usporedo s tendencijom maksimalnog isključenja ljudi iz prometa stvari, poput bespilotnih letjelica u vojnom sektoru. U ranijem kapitalizmu roba i novac kretali su se u istoj ili ljudima bliskoj putanji. No već je tada nicala asimetrična putanja globalne cirkulacije: iz kolonija u metropole rjeđe su dolazili ljudi nego sirovine, uključujući egzotično bilje (Preston, 2003: 196). Od kraja 20. stoljeća asimetrični obrazac razvio se u punoj mjeri s enormnim viškovima proizvoda na Sjeveru koji cirkuliraju na sve strane i enormnim brojem ljudi na Jugu koji nemaju gdje naći posao.

Kapitalizam je pokrenuo masovnu proizvodnju za tržište agrarnih proizvoda, poput šećera i ruma na Karibima, koji su se proizvodili i prije. Šećer se proizvodio tisućama godina za lokalne potrebe i na osnovi lokalnog znanja, a proizvodnja je bila komplicirana i fizički naporna. ${ }^{28}$ Kolonijalnom ot-

28 Velika slatkoća šećerne trske, uzgojene još u osmom tisućljeću prije nove ere Egiptu, u Novoj Gvineji u 9. stoljeću svidjela se indijskim trgovcima, koji su njezinu proizvodnju prenijeli u Indiju, odakle se proširila Perzijom. Šećer je dalje »migirirao« u jugoistočnu Aziju. Rani islamski pokreti prenijeli su trsku i znanje o proizvodnji šećera u arapske dijelove Sredozemlja. Kršćanski križari upoznali su se s njom na Kreti, Cipru i Siciliji. Proizvodnja šećera odvijala se u više faza i zahtijevala brojnu i discipliniranu radnu snagu jer je jedino proizvodnja naveliko bila isplativa (opširnije u: Drayton, 2002). Kolumbo ju je na svome drugom putovanju prenio u Santo Domingo, Cortez ju je donio u Meksiko, a Pizzaro u 
kriću raznih začina, kave, soje i egzotičnog voća također je prethodila duga povijest njihove upotrebe, naturalne i komercijalne, pa i prometa na veće udaljenosti (usp. Blaut, 1993: pogl. 3). Dolaskom kapitalističkih poduzetnika zemlje proizvođači postaju izvoznice samo jednog proizvoda, poput kave na brazilskim plantažama ili šećera na kubanskima (Gunn, 2003: 65 i d.). Uglavnom, sve do druge polovine 20. stoljeća proizvodnja je nezamisliva bez radne snage. Nakon toga njihove se putanje razdvajaju. Neokolonijalni kapitalizam teži proizvodnji roba sa što manjim udjelom ljudskog rada. Iako je u posljednjih stotinjak godina radnik stekao svoja prava, njih kapitalizam u biti nikada nije iskreno prihvatio. To je glavni razlog zaustavljanja protoka radnika s Juga i povećanja protoka proizvoda (sa sve većim udjelom znanja, kao dodane vrijednosti) sa Sjevera na Jug.

$\mathrm{U}$ isto vrijeme ekonomija Sjevera ulazi u virtualni prostor kao novi kontinent na kojem otkriva ekvivalente Kolumbova »raja«. Sada se namjesto rijeka iz Ivanova evanđelja u mitsku dolinu slijevaju rijeke špekulantskih papira koji zamjenjuju klasični novac na burzama dionica i prekrajaju »realnu ekonomiju «, njezine tvrtke i radnike u malu i vitku figuru koja sve manje troši, a sve više ubacuje u stroj koji »sve čvrsto pretvara u dim «i koji stoga poprima gigantske razmjere. U njemu sve sagorijeva, ne samo rad i priroda nego i kapital. Ovako glasi jedan naoko bezazleni savjet novog menadžmenta: »Nekoliko je načina da se poveća ekonomska produktivnost, ali je najbolji (...) poboljšati oruđa koja upotrebljavate da načinite pitu. Drugi 'inputi' - rad i kapital - ne povećavaju produktivnost $\mathrm{u}$ toj mjeri zbog toga što dobici od njih opadaju (diminishing returns)« (Poe, 2011: 253). U tom lancu sve osim mašinerije i njezinih projektanata postaje nepotrebno.

Da pokažu kako postoji ljepota i tog užasa, pobrinuli su se autori koji s vedrinom svojstvenom isključivo novome menadžmentu pišu o novim globalizacijskim krajolicima. Prema njihovim riječima, globalizacija unapređuje »mnogostranu etnografiju « i omogućuje da se još mnogo toga nauči iz »križanja lokalnih praksa i velikih kretanja stanovništva« (Cobb i DePratter, 2012: 460). Sličan doživljaj Novog svijeta omogućuju lanci roba koje se »raznorodnim vezama... [protežu] od [državnih] granica do njiva, polica u supermarketima i agencija za standardizaciju [proizvoda] do migrantskog rada, aparata za kontrolu kvalitete i tako dalje« (Berndt i Boeckler, 2011: 1075). Ta euforična vizura napadno strši pored depresivnog dojma što ga ostavlja kraj priče o novim krajolicima, krcat traumama bezbrojnih ljudi

Peru itd. Početkom 17. stoljeća proizvodnja šećera bila je najveća u tropskim područjima i najviše se koristila robovskom radnom snagom (Godshall, 2007: 1403-1404; Drayton, 2002: 98-105). Kapitalizam je preuzeo tu praksu i povećao količinu robovske radne snage. 
koji su zbog globalne centrifuge ostali na cjedilu i pokušavaju preživjeti u prstenovima nagomilanog smeća »uspješnih « industrijskih gradova. Novi lûk kapitalističke »ontologije« sada spaja sudbinu čovjeka kao rodnog bića, određenog sudbinom umirućeg tijela, sa sudbinom milijarda ljudi koje financijalizirana ekonomija odbacuje kao beskorisne predmete. Nekada je dúga bila nebeski lûk nade, mitska skela za »seobu duša«. Na tom je mjestu sada duh kapitalizma, »špekulativno zgrtanje bankovnog novca radi proizvodnje buduće vrijednosti« (Ingham, 1998: 11), koji se radnicima ceri kao džin koji je izišao iz boce u kojoj je stanovao tisućama godina »realnoj ekonomiji«, kao i duša u tijelu, čija se vrijednost zasniva(la) na ljudskom radu. Ekonomija neoliberalizma i njena monetaristička doktrina u odnosu na materijalnu ekonomiju, prema tome, predstavlja ono što u ontologiji predstavlja »spiritizam«: iluziju ideje osamostaljene od materije. Tako mašinerija iste vrsti, koja se pojavljuje od apokaliptičkih monstruma do nacističkih peći, dizajnira najveće »oružje za masovno uništenje«: novac. Poput Behemota, novac sve proždire. Udobno se smjestivši u fotelji špekulantskog duha, kapitalizam se na Sjeveru »brahmanizira«. Njegove elitističke mantre o društvu znanja trebale bi ostvariti jamačno apsurdan zahtjev: osigurati perpetuiranje kapitala iscrpljivanjem svijeta života (usp. Birch i Cumbers, 2010).

Ideja bez materije, duša bez tijela, rad bez radnika, zarada bez obzira na siromašenje većine ljudi - sve te povijesne zablude sada se stapaju i prerastaju u globalno neodrživog i nepodnošnjivog tiranina, iluziju zastrašujućih razmjera, koja međutim raspolaže kolosalnom financijskom i vojno-industrijskom mašinerijom kojom se okomljuje na preostali svijet života. Upućuje li i povijest kretanja ideja na istu tendenciju nestajanja zbiljskoga u ideji, pretvaranja čvrstoga u dim?

\section{Kretanje ideja}

Pretpostavka o stvaranju svijeta iz Ničega svojstvena je samodovoljnim sustavima općih ideja koje se radije vraćaju svojoj narcisoidnoj samopredodžbi nego deduciraju i vezuju uz nešto što ne priliči njihovoj taštini: materiju, iskustvo, praksu, svakodnevni život s horizontom vedrine spram neposredne budućnosti. Za razliku od općih ideja život je jedini dijalektički proces koji rješava proturječnosti i omogućuje daljnji razvitak različitih oblika postojanja kao održivih suprotnosti. Prepoznaje se u idejama koje nemaju samo jedno polazište ili odredište, koje su otvorene prema novim iskustvima i jedino se na taj način obnavljaju i preobražavaju, omogućujući konfiguriranje elemenata novih svjetova života. Samodostatne fiks-ideje 
koje odbijaju provjeru u praksi pripadaju ideologijama samovoljnog vrha hijerarhijskog društva. On uvjerava da je postojeća zbilja prikazana kroz njihovu vizuru u biti nepromjenjiva, $u$ prijevodu na jezik demokracije: nepodvediva pod utjecaj slobodne volje i dijaloga među ljudima. Iz toga se izvlači obvezni zaključak da sudbinu određuje sila izvan domašaja većine ljudi, a zastupa ju vladajuća klasa. S obzirom na silinu otpora promjenama te kozmologijske sheme, koja se snažno osjeća u zrelim demokracijama koje počivaju na kapitalističkoj ekonomiji, koja nikada nije bila niti će ikada biti demokratska, nije čudno što načela jednakosti i slobode (za sve) sporo ulaze na mala vrata, a brzo izlaze na velika.

Isti obrazac djeluje u kretanjima ideja u modernoj epohi. Na to upozorava i Sorokin ističući da kulturna i društvena pokretljivost bitno ne mijenjaju sustav nejednakosti, nego ga dopunjuju. Jedan od dokaza za to jest geneza spoznaje istine u zapadnoj kulturi koja završava izvjesnom ispraznošću, korelatom prirodoznanstvene spoznaje praznine kao ničim potpomognute roditeljice svijeta. Poslužit ćemo se u tu svrhu Sorokinovim prikazom različitih sustava poimanja istine od 580. p. n. e. do 1920. n. e., od grčko-rimske kulture do začetka masovne kulture Zapada. To su: empirizam (izvor spoznaje istine jest senzorna percepcija), racionalizam (istina dohvatljiva umom), misticizam (istina dohvatljiva nadosjetilnom percepcijom), skepticizam (sustavna sumnja u mogućnost spoznaje istine), fideizam (istina sadržana jedino u vjeri) i kriticizam (istina je pojavna kategorija, a transcendentna je istina nedostižna, ali i nepotrebna ljudima ${ }^{29}$ ); na kraju, prema Sorokinu, glavnina (masovnog) društva na Zapadu odbacuje idejne osnove zbilje i priklanja se vulgarnom empirizmu, senzualnim (sensate) doživljajima, trivijalnim shvaćanjem istine (Sorokin, 1957), zapravo nezainteresiranošću za bilo kakva krupna pitanja, čija rješavanja lakomisleno prepušta vladama i ekspertima.

I Sorokinov životni put odražavao je takvu kulturnu mijenu. Najprije je bio socijalist protivnik Oktobarske revolucije, nakon čega je jedva izvukao živu glavu (i to zahvaljujući tome što ga je Lenjin pomilovao) i emigrirao u SAD u doba koje je jedan drugi emigrantski intelektualac, Adorno, izbjegao u SAD pred njemačkim nacizmom, opisao kao malograđanski duh okupiran medijima, kulturnu katastrofu (Adorno i Horkheimer, 1989). Ta se kvalifikacija podudara sa Sorokinovim opisom posljednje etape »čulnog « stadija (zapadne) kulture: ulične reklame, film, ilustrirane novine, radio i sve drugo što favorizira percepciju nasuprot misaonosti. U oba slučaja kon-

${ }_{29}$ Po svemu sudeći, Sorokin ovdje poistovjećuje kritičnost (criticism), skeptičnost i pragmati$z a m$, što je, tako nerazlučeno, upitno. O Sorokinovu »integralnom poimanju« spoznaje u društvenoj znanosti vidi u: Jeffries, 1999. 
zervativni, elitistički duh zgraža se nad profanacijom (visoke) kulture.

Taj rezultat kritičkog razumijevanja povijesti ideja, koja završava u Americi, valja pažljivo razmotriti. Ono što danas vidimo kao paralelu rascjepu kulture na umnu i osjetilnu, elitnu i pop-kulturu, »ideju« i »zbilju«, raspad je ekonomije na »realnu« i »fiktivnu«, radnu i financijsku. Iako su građeni mnogi mostovi između dviju kultura, od »Tri tenora« do Maksima Mrvice, dojam kulturne katastrofe ostaje neizbrisiv sve dok se opća razina obrazovanja ne podigne do te mjere da »spore poruke« visoke kulture, bilo klasičnog romana, bilo Kantove rasprave o ćudoređu, postanu ako ne potpuno razumljive, a ono predmetom većeg interesa $u$ odnosu na »brze poruke« novih medija.

Unatoč diferencijaciji i usponu novih ideja, kao što je demokracija, njihov uspjeh nije moguć u kulturi rascijepljenoj između uma i osjećaja. Svijet je istinska cjelina, ali se pokorava silama podjela, razdora i razaranja, pa je činjenična istina nešto posve drugo nego idejna istina. A novo znanje raste na takvoj podlozi: ubrzanom prodoru u tajne prirode i društva uz istodobnu odbojnost prema spoznatome. Takvim odcjepljivanjem (raz)uma od osjećaja znanje na Sjeveru raste usporedo s porastom neosjetljivosti na patnje ljudi Juga. Novi, »brahmanistički« kapitalizam ulaže u stvaranje novih znanja i tehnologija čije formule, od proizvodnje lijekova do najsofisticiranijeg oružja, čuva od dohvata država, a osobito militantnih pokreta, na Jugu. S druge strane, na Jugu rastu antizapadnjački pokreti nošeni provalama bijesa i potragom za prečacima do cilja; drugim riječima, cvjeta kriminal svih vrsta.

Odakle izvire povijest ideja koja završava polarizacijom na hladni sjeverni vjetar znanja i tropski južni vjetar užarenih emocija? Povjesničari ideja, bez obzira na neslaganja u vezi s (dis)kontinuitetom između starih i novih ideja ili razlikama između prirodoznanstvenih i društveno-humanističkih spoznaja (Bevir, 2004: 223-253; Watson, 2005: 743-746), rijetko pitanje ideja i znanja stavljaju u širi razvojni kontekst. Poznato je da nerazvijene zemlje preuzimaju znanja o razvoju (tehnologije, ekonomije i demokracije) iz razvijenih zemalja (Simmons, Dobbin i Garett, 2003), ali je primjena tih znanja upitna. Primjena ne znači puko oponašanje uzora (Castelfranchi, 2001; Hoffman i Zhao, 2007), nego fleksibilnu prilagodbu analitičkih ideja, »oko čega se postiže suglasnost i različita znanja prenose različitom auditoriju « (McNeill, 2006: 334). Istim se putem vjerojatno može ostvariti ideja dugotrajnog mira. Ali povijest ideja pokazuje da se najdjelotvornije ideje premještaju u drugom smjeru, iz kabineta $\mathrm{u}$ industrijske pogone s namjenom koja s mirom nema mnogo veze ili ga potkopavaju kao i zemaljsku nadu, prije svega 
proizvodnjom oružja kao najsofisticiranijom i najtraženijom robom koja se kreće na relaciji Sjever - Jug.

Moramo se vratiti mitskoj povijesti da bismo bolje razumjeli znanstvenu. Jedan bog ili jedan od bogova stvara ljude ili bilo koji oblik običnoga, smrtnog života u svom preobilju vremena. Ne zna se je li se sa stvaranjem namučio ili je to učinio u tili čas, ali razmišljanja suvremenih fizičara govore u prilog prvom slučaju, naime da su milijarde godina bile potrebne da se iz bezbroj sudara anorganskih čestica stvori složenija molekula bjelančevina, pra-DNK, kao izvor života (Hawking, 1996). Ponovo ne ulazeći, zbog pluralističkog obzira, $\mathrm{u}$ pitanje istinitosti jedne ili druge priče (svaka je istinita na svoj način), obje dijelom nose pečat ideologije gornje društvene klase. To je dio društva iz kojeg isijava ista ona neosjetljivost prema sudbini donjih slojeva društva kao i bog(ov)a ili prirodnog odabira prema živim stvorenjima, uključujući čovjeka.

U eklezijastičkoj verziji raspadajućega (u fizici: entropijskoga) univerzuma ključni nadomjestak pruža ideja seobe duša u drugi, često bolji, svijet. $\mathrm{U}$ tome je ključ uspjeha religije u odnosu na znanost, jer toliki broj životnih gubitnika ne može naći svoj raison d'être u svjetonazoru tragedije, priče o junacima, u kojoj običnoj, prirodnoj, anonimnoj, mirnoj, »ženskoj «smrti, smrti izvan bojišta, nema mjesta, kao ni povoda za dugo pamćenje. Tragedija pak veliča ulogu junaka i bogova, drugim riječima elitizam. Nova, kapitalistička aristokracija rado prihvaća scijentistički jezik s tragičnom poantom. Razlog je razumljiv, jer ta klasa namjesto junaka i bogova veliča, također u tragičnom fonu, slijepe sile prirodnih zakona u kojima duše nema niti je može biti, kao ni milosrđa, zato što se takav svijet gradi u slavu manjine i na sramotu većine.

Povijest kruženja različitih ideja o istini završava tamo gdje i mit o Početku: u praznini. U monističkom univerzumu migracije imaju jednosmjeran tok na čijem početku i kraju nedostaje jedan element, bilo ideja ili materija. U jednoj od etapa širenja i usložnjavanja univerzuma zajedno migriraju ljudi, životinje, stvari i ideje. Na kraju, kao i na početku, tog univerzuma opstoji praznina, lagana kao i metafizička Ideja. U njoj, prema suvremenoj kozmologiji, stane taman toliko energije koliko je potrebno za eventualnu novu eksploziju. Tu posvudašnju prazninu stari su Grci zvali pneuma (duša). 


\section{Seoba $d u \check{s} a^{30}$}

Smrt je najveća katastrofa za čovjeka i druga živa bića, iako ni u tom slučaju energija, prema prvom zakonu termodinamike, ne nestaje. No, prema drugom zakonu termodinamike, koji upućuje na rastuću entropiju, nered među molekulama, odnosno smrtonosni ishod svega živoga, tako visoka cijena života neizbježna je. Energija ne nestaje, ali se pojedini život nužno gasi da bi učinio mjesta novoj jedinki. Dualistička argumentacija govori u prilog pretpostavljenog postojanja višestrukih univerzuma života, »ljuljačke « zahvaljujući kojoj se preobražavamo od mladosti do starosti i natrag i pritom, za mnoge neopazice, prelazimo »čitavi«, s nenarušenom sintezom, životnom cjelinom duše i tijela, granice između paralelnih ili simetričnih svjetova. Taj argument uperen je, više smislom nego empirijski, više umski nego razumski, protiv monističkog argumenta u prilog smrti i do tog ćemo »oplođivanja« besmisla smislom doći nakon prikaza mita o »seobi duša«, koji je izrastao na iskustvenom tlu monizma. Mi vidimo da sve umire i sve se rađa $u$ nepovratnom redoslijedu, a ne vidimo transcendentalni preobražaj, ne vidimo Isusovo novo tijelo i odijelo, kao što su to, navodno, vidjeli njegovi učenici. Umjesto toga radije se vjeruje u transmigraciju duša (grč. metempsihoza), u biti monistički (idealistički) odgovor na monističko iskustvo suprotnog predznaka (materijalističkoga). Mit o putovanju besmrtne duše nakon tjelesne smrti, vjerojatno potekao iz traumatične reakcije na tu iskustvenu činjenicu, susreće se ne samo u religijskim nego i filozofijskim naučavanjima Pitagore i Platona, možda nastalima po uzoru na staroindijski nauk o reinkarnaciji. ${ }^{31}$ Slično budističko naučavanje bliže je međutim dualističkoj, materijalističko-idealističkoj ontologiji jer duša u toj perspektivi samo u transu živi izvan (nekog) tijela. Također, budističko naučavanje odbacuje i Atman kao sveopće načelo ili božanstvo. ${ }^{32}$

Magijski modus vjerovanja u seobu duša, blizak spiritizmu, izvire iz primitivnih religija duhova (pokojnika). Manje proturječan način, bliskiji i običnom iskustvu i znanstvenoj empiriji, poduprt kvazimaterijalističkim elementima, nalazimo u spomenutome novozavjetnom prikazu uskrsnuća Kristova (neraspadnutog) tijela i kvazimasonskoj udruzi Vaskrisenje. ${ }^{33}$

30 Radi jasnoće dualističkog poimanja različitosti dviju dimenzija života, koje ujedno označuju njihovu nerazdvojivost, terminologija koja se odnosi na duhovne fenomene ovdje je sažeta (i u odnosu na Hartmanna, a pogotovo teologijska razlikovanja) - tako da su duša, duh, ideja i subjekt uzeti kao sinonimi.

31 http://www.english.hawaii.edu/criticalink/plato/terms/metem.html (23. 05. 2014.).

$32 \mathrm{http}: / /$ www.hinduwebsite.com/buddhism/transmigration.asp (23. 05. 2014.).

$33 \mathrm{U}$ tome postrevolucionarnom kružoku besmrtnost je bila uvjetovana podrškom 
U potonjem slučaju tradicionalno rangiranje duhovnog i materijalnog izokrenuto je: duhovno predstavlja nižu razinu postojanja od materijalnoga. $\mathrm{U}$ jednome suvremenijem obliku revolucionarne misli na ljevici kao da se želi ispraviti (monističku) pogrešku, pa materijalno poprima magičnu moć, imanentnu dualističkoj ontologiji, zbog čega se svakodnevica promeće u nešto izvanredno. ${ }^{34}$

Iako se neki elementi vjerovanja u seobu duša mogu naći kod ranih kršćanskih otaca i gnostika, ono je u kršćanstvu prihvaćeno tek u 17. stoljeću, i to ne u crkvenom središtu, nego okultnim društvima rozenkrojcera (Rosenkreutzer - »križari ruža«). Vjerovanja o seobi duša postoje i kod starih Egipćana, kod druida i Gala, u grčkim eleuzijskim misterijima, židovskoj kabali i kod autora raznih provenijencija, od mističnog Swedenborga do skeptičnog Humea (Magnus Incognito, 1968). Riječ je dakle o raširenom vjerovanju koje uobličuje univerzalnu težnju preživljavanju u drugim prostorima u smislu srodnome sekularnim migracijama. No postoji bitna razlika. Život nakon smrti nije moguć u monističkoj perspektivi univerzuma, ali je moguće pomaknuti gornju granicu života i možda je to, s dodatkom mašte koja vodi ususret drugim univerzumima, povezano s daljnjim seobama u nove (svemirske?) prostore. Tako nešto ne može se empirijski potkrijepiti, ali se može pretpostaviti što bi to moglo dovesti do velikog prijelaza iz univerzuma u multiverzum. Presudno je etičko-sociološko stanovište: učvršćenje generativne veze između jednakosti, slobode i solidarnosti s jedne strane, i druge strane, na kojoj se, pretpostavljamo, nalazi drugi i do sada nedohvatljiv svijet, dakle između etosa slobodnoga egalitarnog društva i transcendencije. ${ }^{35}$ Naprosto, od hijerarhijskih prepreka ne možemo dobro vidjeti ni svoje bližnje, a kamoli svemirsku braću i sestre. »Treće oko« otvara se kada prva dva ugledaju svoju ljubav i sreću u drugome dragom biću.

boljševičkoj revoluciji. Sastanke kružoka posjećivao je i Mihail Bahtin (Brandist, 2002). Slično se vjerovanje proteže u dijelu ruske avangarde koji je imao ambiciju obnoviti duh izvornoga kršćanstva (npr. Blok i Šklovski - usp. Flaker, 1984), kao i imaginariju astralnog tijela u New Ageu, no najviše u idejama o pomlađivanju tijela, koje izvore imaju u starijim religijama.

34 Riječ je o parafraziranju jedne misli marksističkog filozofa Henrija Lefebvrea i sižea i likova u književnosti magijskog realizma, koji je, nastavljajući se na Louisa Borgesa, inaugurirao Gabriel García Márquez, a koji je pokušavao interpretativno objediniti takozvani magijski marksizam (usp. Merryfield, 2011).

35 Moguće razvijenije civilizacije od naše u svemiru nezamislive su na osnovi hijerarhijskih i antagonističkih načela. Bogovi ili nasljedne elite, kao njihovo otjelovljenje, bilo u jednini ili množini, monarhijski ili oligarhijski, opstoje samo u civilizacijama zasnovanima na dugotrajnoj društvenoj hijerarhiji i despociji. Takva civilizacija očigledno vodi uništenju većeg dijela ovozemaljskog života i, također vjerojatno, samouništenju. Katastrofa je zaštitni znak takve civilizacije, a masovne migracije posljednji su i sve uzaludniji pokušaj bijega od katastrofa. 
Jedino porazom svih režima, od vojnih i crkvenih do ekonomskih i državno-političkih, koji poništavaju život i njegove vrijednosti i smatraju to svojim isključivim pravom, uključujući činjenje masovnih zločina, za koje, zahvaljujući svojoj samoapsolutizaciji, nemaju kome odgovarati (većina velikih korporacija i država) i, nasuprot tome, izgradnjom društva u kojem se ljudi međusobno pomažu i podupiru u vlastitom interesu, raste transcendirajuće iskustvo neprekinutoga individualnog i zajedničkog života. Ipak, ni u tim uvjetima prijelaz granice između »ovostranog « $\mathrm{i} »$ onostranog « ne zbiva se nenadano, poput mađioničarskoga iluzionističkog trika s nestancima predmeta i ljudi, nego produljenjem »ovostranog « života, koji $\mathrm{u}$ jednom razdoblju, gotovo neopazice, prelazi $\mathrm{u}$ »onostrani«, ustvari novu etapu istog puta. Sveukupno, etički i estetski ${ }^{36}$ oblik društva određuje izvjesnost transcendencije kao kretanja cjelokupnog i neoštećenog svijeta života u novoj dimenziji. Takvo iskustvo postaje utoliko vjerodostojnije ukoliko ima više zajedničkih dobara, međuzavisnosti, osobito solidarnosti prema ljudima i dugim bićima kojima je potrebna pomoć. Takva se društvena ekonomija zasniva na razmjeni darova. U njezinu je sklopu natjecateljska ekonomija sporedan mehanizam, sličan natječaju za kreativnije i manje sigurne poslove, ali uzbudljive i u jednom razdoblju najvažnije za daljnji razvoj, namijenjene poticanju ekonomskih interesa i ulaganja.

Glavni problem $\mathrm{u}$ razumijevanju potrebe za bestjelesnom seobom na drugi svijet nisu šarlatanski vođe koji hoće nabrzinu, kao novi bogataši novac, steći karizmatski ugled, nego je to porast broja njihovih sljedbenika, ljudi koji svoju posljednju šansu vide u smrti. ${ }^{37}$ Moguće je da popularnost NLO-a i sličnih predodžaba o svemirskim susjedima proizlazi iz normalne želje za seobom u druge prostore, koja je presudno i naše pretke potaknula na dalek put. Za razliku od planetarnog razgranavanja života spiritistički modus vjerovanja u seobu duša ima udjela u slučajevima kolektivnih samoubojstava. ${ }^{38}$

36 Civilizacija na višemu razvojnom stupnju nije samo pravednija nego i ljepša od naše današnje, njezinih stršećih visokih zgrada, drečećih kakofonijskih boja reklama i glasova raznih vođa, širećih smradova ratom masakriranih tijela, sve većih prstenova bijede i popucalih veza između kičastih poruka i licemjernih namjera i (ne)djela.

37 Pritom ne mislim na bolesnike $u$ posljednjem i najbolnijem stadiju teške bolesti; mnogima od njih isključivanje aparata za održavanje na životu i, u najtežim i najbeznadnijim slučajevima, eutanazija najracionalnija su rješenja. Ni u perspektivi monističkog univerzuma, života bez zagrobnog nastavka, smrt bez ostatka nije najgori ishod (u usporedbi s produljenim agonijama i torturama).

38 Osim notornih bombaša samoubojica iz redova ekstremnih islamista, eklatantan primjer nesporazuma na »svemirskoj vezi« jest samoubojstvo 39 članova skupine Heaven's Gate, koji su vjerovali da će im duše i tijela uskrsnuti u svemirskom brodu (u simboličnom srod- 
Unatoč svemu tome i nasuprot spiritističkoj obmani vjerovanje u seobu duša moguće je i razložno uvrstiti u kategoriju svijeta života, odnosno migracija. Vjerovanje predstavlja potrebu za kretanjem analognim sekularnim seobama ili putovanjima. No upotreba tog mitologema pobjede nad smrću u apokaliptičkom smislu, s ciljem uništenja ovozemaljskih neprijatelja, kao u slučaju ratova čiju predvodnicu čine džihadistički bombaši-samoubojice, primjer je ne samo nakaradnog nerazumijevanja cjelokupnog fenomena života nego i prirodne smrti u uvjetima mira i nepostojanja pogibeljnih opasnosti, što je normalni način razumijevanja smrti među (normalnim) religioznim osobama. ${ }^{39} \mathrm{U}$ tom smislu dušu je moguće adekvatno prispodobiti kao simbolički kontejner, brod u crkvenoj arhitekturi, u kojem se nalaze "pripravnici« za drugi svijet, nepodijeljena zajednica klera i pastve, što nimalo ne nalikuje na putnike $\mathrm{u}$ Titanicovim razredima. Iako je tek od srednjovjekovnog razdoblja duša prikazana biomorfno, a nakon toga antropomorfno, te su predodžbe, kao i arhitektonska, prilagođene, nasuprot eteričnosti duše u spiritizmu, ovozemaljskim oblicima življenja. ${ }^{40}$

Pokušajmo sada oblikovanje transcendentne kategorije migracija još čvršće povezati s korporealnim migracijama. ${ }^{41}$ Premda će u sljedećemu, zaključnom odjeljku o tome još biti riječi, valja upozoriti na empirijsko opovrgavanje zapažanja, koje je donedavno bilo zaštitni znak sociologije religije, prema kojem napredovanje prema društvu blagostanja i porast povjerenja $\mathrm{u}$ znanost nužno vode opadanju interesa za religiju, uključujući vjerovanje u život nakon smrti (usp. Davie, 2007; Warner, 2010). S druge strane, i kod re-

stvu s crkvenim brodom i ženskom maternicom). Sličan je slučaj kolektivnog samoubojstva 913 pripadnika sekte People's Temple u Guyani.

39 U nedavnom intervjuu Aziz efendija Hasanović, predsjednik Mešihata Islamske zajednice u Hrvatskoj, osvrnuvši se na uspostavu novoga kalifata, Islamske države Iraka i Levanta, rekao je da to što se tamo čini »nema veze s islamom ni Božjom voljom « (Vurušić, 2014: 26). Ako i nije svaki put religijska, potreba za mirom i životnom izvjesnošću svakako je ljudska.

40 Neke religije negiraju postojanje duša kod životinja, što predstavlja otisak antropocentrizma u kombinaciji s kolonijalnim rasizmom, prema kojem je novi život moguć tek poništavanjem zatečenog života. Isto tako, najstariji oblici kolonijalnog rasizma negirali su da ljudi crne rase imaju dušu.

${ }^{41}$ Među prvima je čvršću vezu između imaginarnog i korporealnog raja uspostavio Kolumbo pozivajući se na opis četiriju rijeka iz Ivanova evanđelja. Ta analogija drugog svijeta (San Salvador, u slobodnom prijevodu »zemlja našeg Spasitelja «) podsjeća, ako ne po sadržaju, a ono po stereotipnosti, na pretkolonijalnu imaginativnu kartografiju drugih kontinenata. Svaka sličnost Ivanovih slika s oblicima želja u stanju svijesti stimulirane opijatima nije predmet ovog rada, ali ni ta mogućnost ne isključuje utopijsku težnju, žudnju za boljim svijetom koja se pojavljuje u širokoj paleti ljudske aktivnosti, od slikarstva i revolucionarnih avangardi do »običnih« migranata. 
ligioznih i nereligioznih ljudi raste interes za produženjem ovozemaljskog života. I ljudski se život doista značajno produljio u razvijenijim dijelovima svijeta u posljednjih pola stoljeća, najviše zahvaljujući napretku medicine i boljim ekonomskim uvjetima života. No i ta činjenica, kao i egalitarna tendencija u cjelini, može postati privremenom. Zbog produbljivanja socioekonomskog jaza i ubrzane privatizacije zdravstvenih usluga u mnogim je zemljama samo imućnijim građanima omogućeno korištenje zdravstvenim i srodnim uslugama usredotočenima na produljenje života. Iako se smrt, opet zahvaljujući napretku medicine, lakše podnosi među bogatima, ona je i za njih, a ne samo za siromašne, neizbježna. Time smo došli do završne točke, za koju nitko ne može jamčiti da ujedno predstavlja početnu točku idućeg puta, ali je moguće nadati se. Što drugo dalje preostaje čovjeku kao biću migracija koje, sudeći prema svim do sada prikupljenim znanstvenim dokazima, u toj dobi, ostarjela organizma, više ne može migrirati? Može li ptica pronaći nova krila? ${ }^{42}$

\section{PREMA KRITIČKO-HERMENEUTIČKOM RAZUMIJEVANJU KATASTROFE I MIGRACIJA}

Katastrofe se pojavljuju u svim svjetovima života i jedna povlači za sobom ostale. Na tu nas činjenicu upozorava posljednja scena Eshilova Okovanog Prometeja, u kojoj propadaju i bogovi i ljudi (vjerojatno izraz egalitarne težnje u društvu atenske demokracije). Pa ipak, simbolička struktura tragedije kao dramske vrste upućuje na dvoznačan ishod katastrofa. Jedan ishod junaku donosi vječno prokletstvo i mrak. Drugi je ishod »egzodus «: zbor odlazi sa scene opjevavajući tragična zbivanja poučnim riječima. Među najpoznatijim egzodusima u drugim kulturnim sredinama svakako su, po svoj prilici više mitski nego legendarni, starozavjetni bijeg Židova iz Egipta, bijeg Židova iz Španjolske i drugih europskih zemalja zahvaćenim antisemitizmom, najposlije iz Njemačke zahvaćene nacizmom, bijeg iz boljševičke

${ }^{42}$ Duša je isprva često bila prikazivana kao ptica, tipična selilačka vrsta. Stih »ljubav je ptica zlatnih krila koja dolijeće u tvoje srca i pjeva«, koji, navodno, potječe iz jedne turske poppjesme (»Aşk altın kanatlı kuş gibidir, kalbine uçar ve şarkı söyler«, http://www.italki. com/entry/195348 /10. 06. 2014./), pticu prikazuje metaforički kao neuništivu (»zlatnih krila ) i jedinim jamstvom neprekidnog života kao (trajne) ljubavi. Time se zatvara, danteovski rečeno, gornji nebeski prsten koji nadvisuje i, preoblikujući se, nadsvođuje pakleni krug što ga generira jednoobrazno zaokružen monistički univerzum te mu tako otvara put u nebo. Time se otkriva jedini mogući identitet transcendentnog prostora. Tvore ga bića koja se međusobno vole i zbog toga ne mogu umrijeti. Izraz »dušo moja « među voljenima znači da nam ono najdraže stanuje u drugima, u njih ulijeće i pjeva poput ptice jer zna da se njezino gnijezdo nalazi kamo god krene(mo). 
Rusije, bijeg Afroamerikanaca s juga na sjever SAD-a, bijeg stanovništva iz nedavnim ratom poharane Bosne i Hercegovine itd. Egzodus koliko-toliko omogućuje preživljavanje uz sigurnije uvjete opstanka većini izbjeglica ili prognanika.

Vratimo se simboličkoj strani tragedije. Ako u spomenutoj sceni i zbor bogova bježi s poprišta drame, taj se prizor može razumjeti i kao izraz vjerovanja u postojanje višestrukih svjetova, pri čemu ulogu posrednika imaju bogovi. Oni zacijelo i mogu, ako hoće, uspostaviti uvjete za drukčiji ishod drame, baš kao i suvremene političke elite u postkonfliktnim multietničkim sredinama. Što se tiče inscenirane tragedije, jedna mogućnost izlaza upućuje na komediju, susjednu dramsku vrstu, koja je kao figura poslužila u Hegelovoj filozofiji povijesti, mjestu iz koje je nastala krilatica po kojoj se povijest dvaput ponavlja, najprije kao tragedija, a potom kao komedija.

$\mathrm{Na}$ drugom kraju račvanja tragedije, koji vodi u egzodus, pravi je protagonist publika. Publika odlazi kući u svoj prostor sigurnosti, zaštićen od strahovitih sudbina oslijepljenog Edipa ili pticama iskljucanog Prometeja. To je mogući put u parodiju. Uostalom, i povijesno ishodiše tragedije više je nalikovalo na maskeradu nego na bojišnicu. Kako napominje Alfred Weber, tragedija je prvotno bila "poluvedra igra « s elementima inicijacije, odrastanja i satire, da bi znatno poslije postala dramom o zloj kobi junaka »na pozadini rezonancije zbora «(Weber, 1987: 236). Teatar tragedije sažima druga, spektakularna iskustva, ishode ratova, građanskih i međunarodnih, kakvih je i u staroj Grčkoj bilo mnogo (usp. Lintott, 1982). Napuštanjem teatarskog prostora, nedugo nakon odlaska zbora, koji predstavlja mitsko središte vlasti, bogove usidrene $u$ kolektivnoj svijesti, gledatelj, intimno potresen tragedijom, svoje šanse ipak traži u svakodnevici, zdravom razumu i prirodnoj, »ženskoj« smrti, u krilu poznate zajednice ljudi, s onu stranu ratne scene. Većina ljudi ipak nastoji izbjeći uvlačenje u (su)kob vojskovođa i državnika i ostati u zavjetrini, bezbrižnijem vremenu, zbog kojeg je vjerojatno Heraklit vrijeme označio kao igru, »dječje carstvo«. U takvu »carstvu« čovjek može, poput Nietzscheovih predsokratovskih Grka, zaplesati kraj svoga groba.

Dvoslojnost tragedije na svoj način komentira i konceptualna umjetnica Agnes Denes. Ona ističe da je svjesna ljudske konačnosti, ali i proturječne težnje beskonačnosti, čiju dimenziju postojanja osjeća kroz umjetničko djelo: »Mogu osjetiti osobu koja stoji iza umjetničkog djela starog više stoljeća. To je za mene dovoljno kao čudo i kao umjetnost« (Ottmann, 2008: 246). Za nju je dovoljno, naravno, ali ne i za iskustvo utemeljeno na razumu, zdravome, običnom ili empirijskom, znanstvenom. Kojoj percepciji onda povjerovati? Ako se nakon toliko vremena od nastanka umjetničkog djela još 
može osjetiti dodirujuća blizina njegova autora ili autorice, onda to ne mora biti samo metafora nego i trag još nedovoljno poznatog oblika svijeta ili svjetova života. No i implikacija besmrtnosti, na što nas ponovo upozorava umjetnost, kao što ćemo uskoro pokazati, mora imati smisla. U suprotnome ona prerasta u lošu beskonačnost, u vjerskom smislu vječno prokletstvo, pakao. Besmrtnost izgleda obećavajuće ako u nju uključimo glavnog protagonista ili protagonistkinju i njegov ili njezin glavni uvjet. Glavni protagonist jest migrant kao čovjek, životinja, proizvodno ili stvaralačko opredmećenje, ideja, duša... sve što se, bježeći od prijetnje katastrofe, čije se izbijanje ne može spriječiti niti se mogu kontrolirati njezine posljedice, kreće prema sigurni(ji)m prostorima. No drugi je uvjet hipotetičnost, pogodbeni oblik, proturječnost spram besmrtnosti (kao i smrti). Smrt nužno ne nestaje svugdje, bilo da je razumijemo kao nestanak, privremeni odlazak ili san. Snaga njezine negacije života po njegovu preobražaju u idući transcedentni prostor mnogo je doduše manja nego u monističkome modusu svijeta. Smrt je takoreći mjestimična, sporadična, povremena, ali ipak izvjesna, i dalje se događa. »Et in Arcadia ego«, poručuje anonimni zapis nekog pokojnog ili već dugo usnulog stanovnika zemaljskog raja. »Ego« koji govori predstavlja personifikaciju Smrti na Poussinovoj slici Arkadije (Panofsky, 2008). Ni u raju nekima ne mora biti lako živjeti, kao što se to, uostalom, dogodilo s mnogim američkim domorocima suočenima s nadirućim bijelim kolonizatorima (koji su im raj pretvorili u pakao). Drugim riječima, sloboda izbora života ili smrti, kao zajamčeno načelo, ne nestaje ni u višem stadiju razvoja civilizacije. ${ }^{43}$ Takvo rješenje moglo bi pomiriti monističku i pluralističku perspektivu univerzuma. U prvoj je život slučajna i kratkotrajna pojava među nebrojenim gomilama anorganske tvari i nepreglednim prazninama. U drugoj perspektivi život cvjeta na sve strane. Ali taj kontrast nije isključiv. Multiverzum omogućuje bijeg iz univerzuma, njegove konačnosti i smrti. Univerzum omogućuje bijeg iz multiverzuma. ${ }^{44}$

Jedan drugi argument protiv apokaliptičkog, »ili-ili« razumijevanja katastrofâ, kao i mogućnosti uklanjanja njihovih posljedica u monističkom univerzumu, kao ambijentu iluzorne suradnje između čovjeka i Boga, može se

43 »Zajednička vlada čovječanstva morat će samo osigurati svim ljudima jednake uvjete da bi mogli preživjeti, a kako će oni trošiti život i odabirati svoju smrt, to ostaje potpuno njihova društvena i privatna stvar« (Supek, 1989: 315).

${ }^{4} \mathrm{U}$ jednome davnom predavanju autora ovog rada skupini liječnika iz Trećeg svijeta o društvenim aspektima bolesti i straha od smrti jedan od liječnika kazao je da su oni pobjegli iz šamanističkoga besmrtnog svijeta u svijet smrti, odnosno zapadnu medicinu, zbog, koliko je autor mogao razumjeti, prijetnje neprekidnog življenja pod terorom šamana kao spiritualnog despota, modusa življenja mnogo goreg od smrti. 
naći u heremeneutičkome povijesnoumjetničkom promišljanju Davida Roskiesa o legendarnim biblijskim i povijesno obilato dokumentiranim katastrofama Židova s vrhuncem, dakako, u Holokaustu: »Katastrofa je, ustvari, oduvijek dio procesa preispitivanja prošlosti (...) [J]er ako je presumpcija čovjeka da djeluje kao uništavatelj, onda je uobličavanje katastrofe u novi niz ploča prastari čin stvaranja izveden na sliku Božju« (Roskies, 1999: 310).

Teško je zamisliti težu osudu Holokausta iz fundamentalno antropološke perspektive. Optužba je adresirana na Boga, koji je u najgori čas po svoj narod ili zaspao ili umro (u multiverzumu to je isto). Ispostavilo se da je, kao i njegova stvorenja, neosjetljiv na ljudsku patnju. Možda je biblijski lik Stvoritelja, despotski osvetoljubivog u Starom zavjetu i bešćutno nečujnog u Novom zavjetu na sinovo mučno zapomaganje, zaslužio da ga suvremena znanost proglasi beznačajnim i porekne mu bilo kakvu egzistenciju ili ulogu u stvaranju svijeta ili evoluciji vrsta. Pa ipak, zamjenom Boga »niskoenergetskim« Ništavilom ili biološkom igrom slučajnosti nije promijenjena zla kob bića, koju mnogi humanisti pripisuju učinku kapitalizma i srodnih totalitarnih režima. Ustvari, u monističkom univerzumu, kao samoproglašenome jedinome, nije čudno što u toj mjeri narcisoidni i ekskluzivno nastrojen lik Istine sve oko sebe, na koncu i sam sebe, uništava. ${ }^{45}$

Obrnemo li pak gore navedenu Roskiesovu rečenicu u fojerbahovskom smislu, u smislu odnosa Čovjeka (stvaraoca) i Boga (stvorenoga), možemo zaključiti da krivnju za zlu kob snosi onaj dio čovjeka ili ljudi koji sliku Boga stvara(ju) prema svojoj rušilačkoj težnji. U pluralističkome, životvornome, univerzumu načelo postojanja utemeljeno je na suprotnoj, graditeljskoj strani čovjeka, iz koje zrači ne samo energija stvaranja nego i simpatija: za izgradnju boljeg svijeta potrebni su mnogi, zapravo svi. Pitanje je jedino može li bolju stranu čovjeka i svijeta afirmirati samo ontološka ideja (pluralnog univerzuma), koja još nije empirijski utvrđena ni praktično razvijena.

Ovdje ne možemo usmjerivati empirijsku ili teorijsku spoznaju razvoja koji bi trajno vodio sigurnosti cjelokupnog života. Umjesto toga možemo samo apelirati na zasnivanje slobode i jednakosti, kao ključnih modernih ideja, u praksi razvoja iz koje može poteći podupiruća znanstvena teorija i empirija unapređenja pluralizma razvoja. Jug i ne može unedogled čekati na pomoć izvana, iz svijeta koji nije ni »njegov« ni »naš«, koji nema svjetsku vladu koja bi se podjednako brinula o svim svojim građanima i područjima,

45 »Antikrist se može roditi i iz same pobožnosti, iz pretjerane ljubavi prema Bogu ili prema istini, kao što heretik postaje od sveca, a vragom opsjednuti iz vidovnjaka. Boj se (...) proroka i onih što su pripravni umrijeti za istinu, jer obično za sobom u smrt povuku mnogo drugih ljudi, često prije sebe, ponekad umjesto sebe« (Eco, 1984: 527). 
umjesto da kao postojeći savez razvijenih zemalja veći dio ostalog svijeta tretira kao strano tijelo i dio propadajućeg svijeta kojem nema pomoći. Stoga jedini mogući odgovor na prijetnju trijumfa rušilačke težnje i, u skladu s tim, težnje stotina milijuna ljudi da se s uništenog Juga dokopaju koliko-toliko očuvanih životnih prostora na Sjeveru, jest prevođenje ontološke ideje o mnogostrukom univerzumu u razvojnu praksu, način života blizak brojnim mikroiskustvima međusobnog pomaganja i solidarnosti. U tom cilju potrebna su nova i veća svjetska ulaganja u alternativni, a ipak $u$ biti moderan, razvoj Juga, kako bi se izbjegla prijetnja nadolazeće katastrofe, razvojne i ekološke podjednako. Na taj način potencijalni iseljenik s Juga sudjeluje u izgradnji društva koja mijenja izgled(e) njegove zavičajne sredine u toj mjeri da se iz nje više ne mora iseljavati ako to ne želi.

\section{LITERATURA}

Adorno, T. i Horkheimer, M. (1989). Dijalektika prosvjetiteljstva. Sarajevo: Veselin Masleša. Agamben, G. (2008). Izvanredno stanje. Zagreb: Deltakont d.o.o.

Appadurai, A. (2013). The Future as Cultural Fact: Essays on the Global Condition. London - New York: Verso.

Arendt, H. (1996). Eseji o politici. Zagreb: Izdanja Antibarbarus.

Bade, K. J. (2003). Migration in European History. Malden, MA - Oxford: Blackwell.

Bauer, S. i Klaassen, M. (2013). Mechanistic models of animal migration behaviour - their diversity, structure and use, Journal of Animal Ecology, 82 (3): 498-508, doi: 10.1111/1365-2656.12054.

Benton, M. J. (2011). Mass Extinctions, New Scientist, 209 (2802): i-viii.

Berndt, C. i Boeckler, M. (2011). Performative regional (dis)integration: transnational markets, mobile commodities, and bordered North - South differences, Environment \& Planning A, 43 (5): 1057-1078, doi:10.1068/a4381.

Bevir, M. (2004). The Logic of the History of Ideas. Cambridge, UK - New York: Cambridge University Press.

Birch, K. i Cumbers, A. (2010). Knowledge, space, and economic governance: the implications of knowledge-based commodity chains for less-favoured regions, Environment \& Planning A, 42 (11): 2581-2601, doi: 10.1068/a43191.

Blaut, J. M. (1993). The Colonizer's Model of the World: Geographical Diffusionism and Eurocentric History. New York - London: The Guilford Press.

Brandist, C. (2002). The Bakhtin Circle: Philosophy, Culture and Politics. London: Pluto Press.

Brysk, A., Parsons, C. i Sandholtz, W. (2002). After Empire: National Identity and PostColonial Families of Nations, European Journal of International Relations, 8 (2): 267-305.

Casanova, J. (2008). Public Religion Revisited, u: H. de Vries (ur.). Religion: Beyond the Concept. New York: Fordham U.P., 101-119. 
Castelfranchi, C. (2001). Towards a Cognitive Memetics: Socio-Cognitive Mechanisms for Memes Selection and Spreading, Journal of Memetics - Evolutionary Models of Information Transmission, 5 (1), http://cfpm.org/jom-emit/2001/vol5/castelfranchi_c. html.

Castles, S. (2004). Why migration policies fail, Ethnic and Racial Studies, 27 (2): 205-227, doi: 10.1080/0141987042000177306.

Cobb, C. R. i DePratter, C. B. (2012). Multisited Research on Colonowares and the Paradox of Globalization, American Anthropologist, 114 (3): 446-461, doi: 10.1111/j.15481433.2012.01445.x.

Czaika, M. i de Haas, H. (2014). The Globalization of Migration: Has the World Become More Migratory? International Migration Review, 48 (2): 283-323, doi: 10.1111/ imre.12095.

Davie, G. (2007). The Sociology of Religion. London: Sage.

Davis, K. F., D'Odorico, P., Laio F. i Ridolfi, L. (2013). Global Spatio-Temporal Patterns in Human Migration: A Complex Network Perspective, PLoS ONE, 8 (1): e53723, doi: 10.1371/journal.pone.0053723.

Dhaouadi, M. (2002). Capitalism, Global Humane Development and the Other Underdevelopment, u: L. Sklair (ur.). Capitalism \& Development. London: Taylor \& Francis, 140-164.

Drayton, R. (2002). The Collaboration of Labour: Slaves, Empires, and Globalizations in the Atlantic World, c. 1600-1850, u: A. G. Hopkins (ur.). Globalization in World History. London: Pimlico, 98-114.

Eco, U. (1984). Ime ruže. Zagreb: Grafički zavod Hrvatske.

The End of the Development-Security Nexus? The Rise of Global Disaster Management (ur. J. Sörensen i F. Söderbaum) (2012). Development Dialogue, 58.

Evans-Wentz, W. Y. (ur.) (1998). Tibetanska knjiga mrtvih. Zagreb: CID-Nova.

Finstad, A. G. i Hein, L. C. (2012). Migrate or stay: terrestrial primary productivity and climate drive anadromy in Arctic char, Global Change Biology, 18 (8): 2487-2497, doi: 10.1111/j.1365-2486.2012.02717.x.

Flaker, A. (1984). Poetika osporavanja: avangarda i književna ljevica. Zagreb: Školska knjiga.

Foran, J. (1997). The future of revolutions at the fin-de-siècle, Third World Quarterly, 18 (5): 791-820, doi: 10.1080/01436599714605.

Giddens, A. (1984). The Constitution of Society: Outline of the Theory of Structuration. Cambridge: Polity.

Godshall, M. A. (2007). Sugar and other Sweeteners, u: J. A. Kent (ur.). Handbook of Industrial Chemistry and Biotechnology, sv. 2. New York: Springer, 1657-1693

Greenblatt, S. J. (2004). Cultural Mobility, http://isites.harvard.edu/fs/docs/icb. topic733185.files/Greenblatt.pdf (23. 05. 2014.).

Greenblatt, S. J. sa Županov, I. G., Meyer-Kalkus, R. Paul, H., Nyíri, P. i Pannewick, F. (2010). Cultural Mobility: a Manifesto. Cambridge: Cambridge University Press.

Greene, B. (2011). The Hidden Reality: Parallel Universes and the Deep Laws of th Cosmos. New York - Toronto: Random House.

Gunn, G. C. (2003). First Globalization: The Euroasian Exchange, 1500-1800. Lanham: Rowman \& Littlefield Publishers. 
Halebsky, S. (2014). Corporate Practices and Harmful Consequences: Learning from the Holocoust, Humanity \& Society, 38 (3): 237-267, doi:10.1177/0160597614537797.

Habermas, J. (1981). Theorie des kommunikativen Handelns. Frankfurt a.M.: Suhrkamp.

Harding, J. (2012). Border Vigils: Keeping Migrant Out of the Rich World. London - New York: Verso.

Hartmann, N. (1949). Das Problem des geistigen Seins: Untersuchungen zur Grundlegung der Geschichtsphilosophie und der Geisteswissenschaften. Berlin: Walter de Gruyter.

Hartmann, N. (1976). Prilog zasnivanju ontologije. Zagreb: CKD.

Hawking, S. (1996). Life in the Universe, http://www.hawking.org.uk/life-in-the-universe. html (10. 06. 2014.).

Hays, G. C. i Scott, R. (2013). Global patterns for upper ceilings on migration distance in sea turtles and comparisons with fish, birds and mammals, Functional Ecology, 27 (3): 748-756, doi: 10.1111/1365-2435.12073.

He, D., Gao, D. i Cai, Q. (2014). Spontaneous creation of the universe from nothing, Physical Review D, 89, 083510, http://arxiv.org/abs/1404.1207 (02. 09. 2014.), doi: 10.1103/PhysRevD.89.083510.

Hein, A. M., Hou, C. and Gillooly, J. F. (2012). Energetic and biomechanical constraints on animal migration distance, Ecology Letters, 15 (2): 104-110, doi: 10.1111/j.14610248.2011.01714.x.

Hoerder, D. (1994). Changing paradigms in migration history: From 'To America' to world-wide systems, Canadian Review of American Studies, 24 (2): 105-127.

Hoffman, D. M. i Zhao, G. (2007). Global Convergence and Divergence in Childhood Ideologies and the Marginalisation of Children, Education \& Society, 25 (1): 57-75, doi: 10.7459/es/25.1.05.

Ingham, G. (1998). On the Underdevelopment of the 'Sociology of Money', Acta Sociologica, 41 (1): 3-18, doi: 10.1177/000169939804100101.

Jayaram, V. Transmigration Of Souls - A Buddhist Perspective, http://www.hinduwebsite. com/buddhism/transmigration.asp (10. 06. 2014.).

Jeffries, V. (1999). The Integral Paradigm: The Truth of Faith and the Social Sciences, American Sociologist, 30 (4): 36-55, doi: 10.1007/s12108-999-1022-6.

Katunarić, V. (1978). Vanjske migracije i promjene u porodici. Zagreb: Centar za istraživanje migracija.

Katunarić, V. (2003). Sporna zajednica: novije teorije o naciji i nacionalizmu. Zagreb: Jesenski i Turk - Hrvatsko sociološko društvo.

Katunarić, V. (2013). Svjetski antibarbarus: uzroci propastibivšeg i nadolaska novog socijalizma. Zagreb: Društvo »Povijest izvan mitova «.

Korošić, M. (1988). Jugoslavenska kriza. Zagreb: Naprijed.

Li, X., Zhang, J. i Yin, M. (2014). Animal migration optimization: an optimization algorithm inspired by animal migration behavior, Neural Computing $\mathcal{E}$ Applications, 24 (7-8): 1867-1877, doi: 10.1007/s00521-013-1433-8.

Lintott, A. (1982). Violence, Civil Strife and Revolution in the Classical City. Baltimore: The John Hopkins University Press.

Lucassen, J., Lucassen, L. i Manning, P. (ur.). (2010). Migration History in World History: Multidisciplinary Approaches. Leiden - Boston: Brill. 
Magnus Incognito (1968). The Secret Doctrine of the Rosicrucians. Yoga Publication Society, http://www.sacred-texts.com/sro/sdr/sdr11.htm (20. 03. 2014.).

Merryfield, A. (2011). Magical Marxism: Subversive Politics and the Imagination. London: Pluto Press.

Marx, K. i Engels, F. (2008). Manifest Komunističke partije, Ekonomija / Economics, 15 (3): 565-596, http://staro.rifin.com/root/tekstovi/casopis_pdf/ek_ec_586.pdf (23. 05. 2014.).

McNeill, D. (2006). The Diffusion of Ideas in Development Theory and Policy, Global Social Policy, 6 (3): 334-354, doi: 10.1177/1468018106069204.

Newton, I. (2012). Obligate and facultative migration in birds: ecological aspects, Journal of Ornithology, 153 (1, supplement): 171-180, doi: 10.1007/s10336-011-0765-3.

Ottmann, K. (ur.) (2008). The Human Argument: the Writings of Agnes Denes. Putnam, Conn.: Spring Publications.

Panofsky, E. (2008). Et in Arcadia ego: Poussin i elegična tradicija. Zagreb: Matica hrvatska.

Poe, M. T. (2011). A History of Communications: Media and Society from the Evolution of Speech to the Internet. New York, N.Y.: Cambridge University Press.

Posner, R. A. (2004). Catastrophe: Risk and Response. Oxford: Oxford University Press.

Preston, R. (2003). "The scenery of the torrid zone": imagined travels and the culture of exotics in nineteenth century British gardens, u: F. Driver i D. Gilbert (ur.). Imperial Cities: Landscape, Display and Identity. Manchester - New York: Manchester University Press.

Radford, G. P. (1991). Hermeneutics: an Intellectual Tradition for Communication Studies, http://www.theprofessors.net/hermen.html (20. 03. 2014.).

Ramsey, G. (2013). Culture in humans and other animals, Biology E Philosophy, 28 (3): 457-479, doi: 10.1007/s10539-012-9347-x.

Reisman, A. (2011). On a Taxonomy for the Literature on Migration, International Migration, 49 (2): 191-206, doi: 10.1111/j.1468-2435.2009.00568.x.

Rohrer, S. (2010). Wandering Souls: Protestant Migrations in America, 1630-1865. Chapel Hill, NC: University of North Carolina Press.

Roskies, D. G. (1999). Against the Apocalypse: Responses to Catastrophe in Modern Jewish Culture. Syracuse, N.Y.: Syracuse University Press.

Runciman, W. G. (1989). A Treatise on Social Theory. Volume II: Substantive Social Theory. Cambridge: Cambridge University Press.

Saunders, D. (2011). Arrival City: How the Largest Migration in History Is Reshaping Our World. New York: Pantheon Books.

Scheers, P. (2001). Hermeneutics and Animal Being: The Question of Animal Interpretation. MAVE Dissertation, Lancaster University, http://www.lancaster.ac.uk/search/?q=He rmeneutics+and+Animal+Being (23. 05. 2014.).

Shaw A. K. i Levin, S. A. (2011). To breed or not to breed: a model of partial migration, Oikos, 120 (12): 1871-1879, doi: 10.1111/j.1600-0706.2011.19443.x.

Simmons, B., Dobbin, F. i Garrett, G. (2003). The International Diffusion of Democracy and Markets, Annual meeting of the American Political Science Association, Philadelphia, August 2003.

Smith, A. D. (1986). The Ethnic Origins of Nations. Oxford: Blackwell. 
The State of Food Insecurity in the World 2010: Addressing Food Insecurity in Protracted Crises (2010). Rome: FAO, http://www.fao.org/docrep/013/i1683e/i1683e.pdf (11. 06. 2014.).

Sorokin, P. A. (1957). Social and Cultural Dynamics. Boston: Porter Sargent Publisher.

Sorokin, P. A. (1959). Social and Cultural Mobility. Glencoe, IL: Free Press.

Steinberg, P. E. (2009). Sovereignty, Territory, and the Mapping of Mobility: A View from the Outside, Annals of the Association of American Geographers, 99 (3): 467-495, doi:10.1080/00045600902931702

Supek, R. (1989). Ova jedina Zemlja: idemo li u katastrofu ili u Treću revoluciju?. Zagreb: Globus.

Tainter, J. A. (2007). Kolaps kompleksnih društava. Zagreb: Naklada Jesenski i Turk.

Tennant, E. (1998). Elinor \& Marianne. Zagreb: Ceres.

Tilly, C. (1993). European Revolutions, 1492-1992. Oxford, UK - Cambirdge, USA: Blackwell.

Uzzoli, A. (2011). The Role of Unemployment in the Run of Life Chances in Hungary, International Journal of Population Research, article ID 130318, http://www.hindawi. com/journals/ijpr/2011/130318/ (10. 06. 2014.), doi:10.1155/2011/130318.

Verdery, K. (1996). What Was Socialism, and What Comes Next?. Princeton, New Jersey: Princeton University Press.

Vurušić, V. (2014). Kalifat je ruglo i sramota čitavog islamskog svijeta, Jutarnji list, 30. kolovoza 2014., 26-27.

Warner, R. (2010. Secularization and Its Discontents. London: Continuum.

Watson, P. (2005). Ideas: a History of Thought and Invention, from Fire to Freud. New York: Harper Collins Publishers.

[Weber] Veber, A. (1987). Tragično i istorija. Novi Sad: Književna zajednica Novog Sada - Dnevnik.

Weber, M. (1999). Politika kao poziv, u: M. Weber. Vlast i politika. Zagreb: Naklada Jesenski i Turk - Hrvatsko sociološko društvo, 161-214.

Zakai, A. (2002). Exile and Kingdom: History and Apocalypse in the Puritan Migration to America. Cambridge: Cambridge University Press. 


\title{
Catastrophes and Migration: A Critical Hermeneutic Approach
}

\author{
Vjeran Katunarić
}

\begin{abstract}
SUMMARY
Departing from Sorokin dualistic ("internal" and "external") explanations of movement and from an extended critical hermeneutic understanding of the life-world, the article first analyzes some examples of mythologems/ideologems of migration. Furthermore, it discusses the connection between catastrophes and migrations in the animal and human world, the movements of things and ideas, especially the myth of the "migration of souls". The main (hypo)thesis relates to the contemporary blockade of mass migration of people from the South to the North, which is taken as a result of the collapse of key development projects arising from the ideology of liberalism and socialism, where, as an anti-modernization response, a part of the South reactivates myth of the "migration of souls". Catastrophic events thus cause (mass) migration, interpreted as a phenomenon of the life-worlds in two ways: firstly, as an object of religious and scientific worldviews that postulate nothingness or disappearance of (individual) species as a precondition for creation (of a new world or new species); secondly, catastrophes are reinterpreted from the perspective of the concept of multiple universes, which is more hermeneutic than analytical. In imperial cosmologies material or ideal element of the monistic assumption of the universe prevails. The prevalence is expressed as the conceptual split between the immortal "migrant" soul and decaying "indigenous" body (idealistic solution) or combined (materialistic solution). The exodus as a motif occurs in many cultures along with the myth of "migration of souls". Nowadays, the myth is reactivated among populations obsessed by militaristic idea of the "holy war". The aggression against the lifeworlds is thus composed of two long-term processes that undermine (utopian) hope for a better life. One process relates to the expansion of the capitalist markets that leads to the impoverishment of most people in the South. The second process relates to substituting secular migration to safer areas by illusory, i.e. apocalyptic scenarios of survival. The author argues that only rational answer to the destructive threat is translating ideas about the multiple universe into new, yet alternative, global investments into the development of the South (and the North). This way, a potential immigrant participates in the building of his/her local environment, whereby his/her (e)migration becomes unnecessary or the subject to free choice.
\end{abstract}

KEY WORDS: catastrophes, evolution, development, migration, mythologhems, "migration of souls", critical hermeneutics 